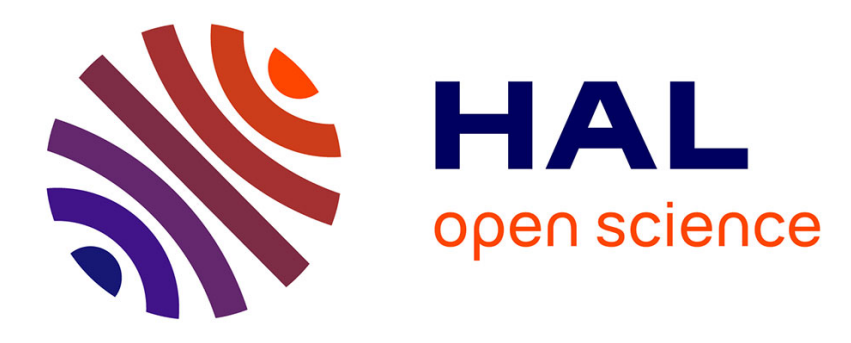

\title{
Average molecular weight of surfactants in aerosols
}

M. T. Latif, P. Brimblecombe

\section{To cite this version:}

M. T. Latif, P. Brimblecombe. Average molecular weight of surfactants in aerosols. Atmospheric Chemistry and Physics Discussions, 2007, 7 (5), pp.13805-13838. hal-00303107

\section{HAL Id: hal-00303107 https://hal.science/hal-00303107}

Submitted on 25 Sep 2007

HAL is a multi-disciplinary open access archive for the deposit and dissemination of scientific research documents, whether they are published or not. The documents may come from teaching and research institutions in France or abroad, or from public or private research centers.
L'archive ouverte pluridisciplinaire HAL, est destinée au dépôt et à la diffusion de documents scientifiques de niveau recherche, publiés ou non, émanant des établissements d'enseignement et de recherche français ou étrangers, des laboratoires publics ou privés. 
Atmos. Chem. Phys. Discuss., 7, 13805-13838, 2007

www.atmos-chem-phys-discuss.net/7/13805/2007/

(C) Author(s) 2007. This work is licensed

under a Creative Commons License.

Surfactants in aerosols

M. T. Latif and

P. Brimblecombe

\section{Average molecular weight of surfactants in aerosols}

\section{T. Latif ${ }^{1}$ and P. Brimblecombe ${ }^{2}$}

${ }^{1}$ School of Environmental and Natural Resource Sciences, Faculty of Science and Technology, Universiti Kebangsaan Malaysia, 43600 Bangi, Malaysia

${ }^{2}$ School of Environmental Sciences, University of East Anglia, NR4 7TJ Norwich, UK

Received: 30 August 2007 - Accepted: 10 September 2007 - Published: 25 September 2007

Correspondence to: M. T. Latif (talib@pkrisc.cc.ukm.my)

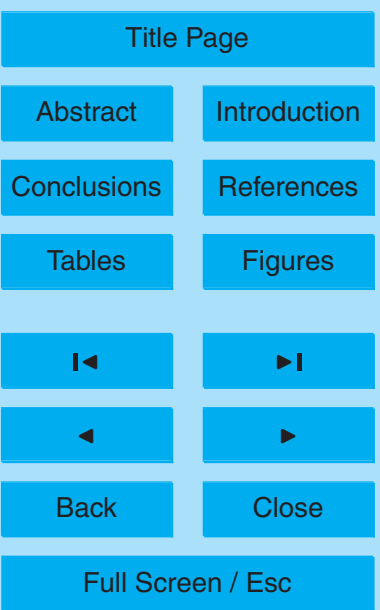

Printer-friendly Version

Interactive Discussion 


\section{Abstract}

Surfactants in atmospheric aerosols determined as methylene blue active substances (MBAS) and ethyl violet active substances (EVAS). The MBAS and EVAS concentrations can be correlated with surface tension as determined by pendant drop analysis.

5 The effect of surface tension was more clearly indicated in fine mode aerosol extracts. The concentration of MBAS and EVAS was determined before and after ultrafiltration analysis using AMICON centrifuge tubes that define a $5000 \mathrm{Da}(5 \mathrm{~K} \mathrm{Da})$ nominal molecular weight fraction. Overall, MBAS and to a greater extent EVAS predominates in fraction with molecular weight below $5 \mathrm{~K} \mathrm{Da}$. In case of aerosols collected in Malaysia the higher molecular fractions tended to be a more predominant. The MBAS and EVAS are correlated with yellow to brown colours in aerosol extracts. Further experiments showed possible sources of surfactants (e.g. petrol soot, diesel soot) in atmospheric aerosols to yield material having molecular size below $5 \mathrm{~K}$ Da except for humic acid. The concentration of surfactants from these sources increased after ozone exposure and for humic acids it also general included smaller molecular weight surfactants.

\section{Introduction}

The extent and composition of the organic layer which typically covers the surface of atmospheric particles affects surface related aerosol properties such as effect on health, the ability of the particles to activate and form cloud droplets, and the aggregation of particles as well as reactions between the particle and gas phase species (Peterson and Tyler, 2002, 2003). Since first mentioned by Blanchard (1964), surface active materials in atmospheric aerosols were believed to be derived from the marine environment (Cini and Loglio, 1997; Giovannelli et al., 1988; Loglio et al., 1986, 1985; Nicolotti et al., 2005; Oppo et al., 1999; Rettori et al., 2005). Surface active materials in the atmosphere are still under study so some points, especially regarding their composition and origin remain under debate. Nevertheless it is clear that they are associated

\section{Surfactants in} aerosols

M. T. Latif and

P. Brimblecombe

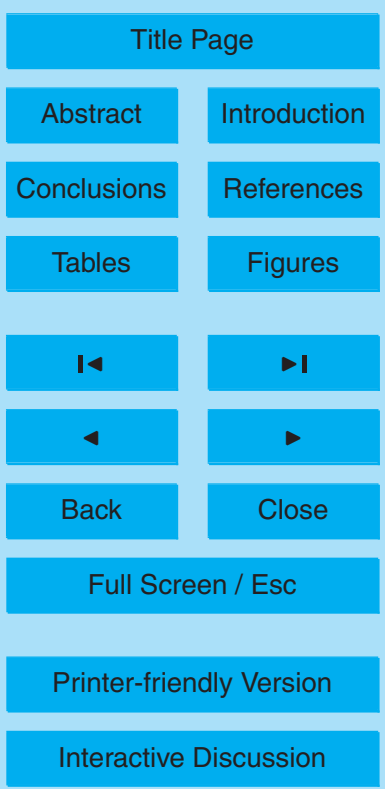


with the water soluble oxygenated and macromolecular polar organic substances of fine mode aerosols (Latif and Brimblecombe, 2004).

The exact chemical nature of candidate surface active components in atmospheric aerosols is still did not clear. Several studies showed that the surface active compo5 nents of both marine and continental aerosols is dominated by aliphatic hydrocarbons and their amphipilic derivatives (Peterson and Tyler, 2002). This was supported by study of Gilman et al. (2004) which indicated that the carbon length of amphipilic compound is the most important factor in determining its interfacial stability and longevity. Analysis using TOF-SIMS by Tervahattu et al. showed a preponderance of long chain 10 fatty acids at the surface of atmospheric aerosol particles (Tervahattu et al., 2002a, b, 2005).

Other researchers suggest that the surface active component in atmospheric aerosols correlated with water soluble organic carbon and humic like substances (HULIS) (Bower et al., 2000; Krivacsy et al., 2000; Zappoli et al., 1999). According 15 to Facchini et al. (1999a) surfactants are particularly polyacidic compounds of high molecular mass represent an average $25 \%$ of the organic solute. The upper limit for the molecular weight of these compounds, likely to consist of mono and di-carboxylic acid and polycarboxylic acids (Bower et al., 2000), is estimated as $3070 \mathrm{Da}$ (Zappoli et al., 1999). Other studies suggest that the molecular weight of humic like substances 20 in atmospheric aerosols is below $1000 \mathrm{Da}$ (Havers et al., 1998; Kiss et al., 2003; Samburova et al., 2005).

Humic substances are typically seen as soil components, and Aitken et al. (1985) characterized these as yellow to black refractory organic substances of high molecular weight. The components of humic materials are separated on the basis of molecu-

25 lar weight where fulvic acid is typically 500 to 5000 daltons (Da), while humic acid is $>5000 \mathrm{Da}$ and can extend to values >1000000 Da (Kiss et al., 2003; Yates and Wandruszka, 1999). Likens et al. (1983) showed that organic substances of molecular weight $(\mathrm{MW})>1000 \mathrm{Da}$ in precipitation accounted for more than $50 \%$ of the total dissolved organic carbon. High molecular weight carbon compounds are believed to be

Surfactants in aerosols

M. T. Latif and

P. Brimblecombe

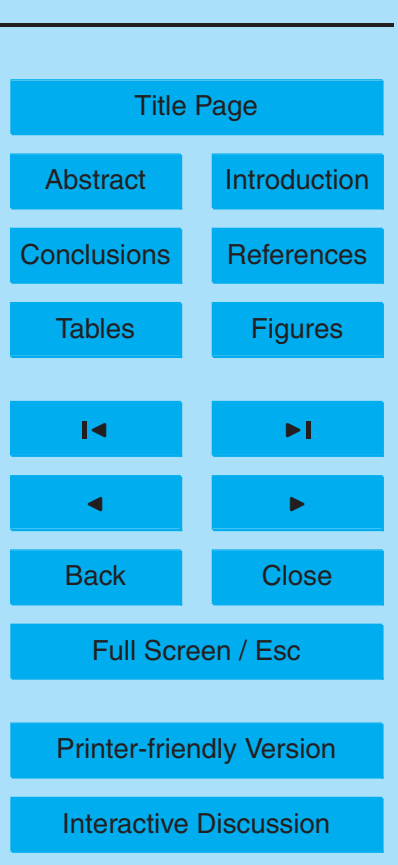

\section{7}


involved in cloud condensation (Facchini et al., 1999b; Krivacsy et al., 2000).

The origin of macromolecular humic substances in atmosphere is still unclear. $A$ small amount could derive from wind blown soil. However, (i) secondary production from high molecular weight substances emitted from soil (Mezaros et al., 1997) , (ii) di-

5 rect biogenic emission and (iii) secondary formation from anthropogenic precursors are thought to be important (Feng and Moller, 2004). They could also derive from photochemical oxidation of volatile organic compounds (Went, 1960). Ozonolysis of organic compounds on aerosols surfaces can alter their chemical properties of (Chughtai et al., 1999) and make the particles more hydrophilic (Weingartner et al., 1997) hinting at a 10 heterogeneous pathway for seconcary production of surfactants.

We have studied the concentration of surfactants in the atmosphere as anionic methylene blue and ethyl violet active substances (Sukapan and Brimblecombe, 2002; Latif and Brimblecombe, 2004, and Latif et al., 2005). This activity appears to be related to the presence humic like substances (HULIS), so the present work has aimed 15 at determining the range of nominal molecular weight of such surfactants present on ambient aerosols.

\section{Materials and method}

A range of experimental measurements determined various characteristics of our samples.

\subsection{Surfactant Concentration}

Surfactant concentration measured as Methylene Blue Active Substances (MBAS) and Ethyl Violet Active Substances (EVAS) used in this study was based on the analysis of samples collected at University of East Anglia (UEA), Norwich in United Kingdom, Universiti Kebangsaan Malaysia (UKM), Bangi and Engineering Campus, Universiti

Sains Malaysia (USM), Penang and Universiti Malaysia Sabah (UMS), Kota Kinabalu

Surfactants in aerosols

M. T. Latif and

P. Brimblecombe

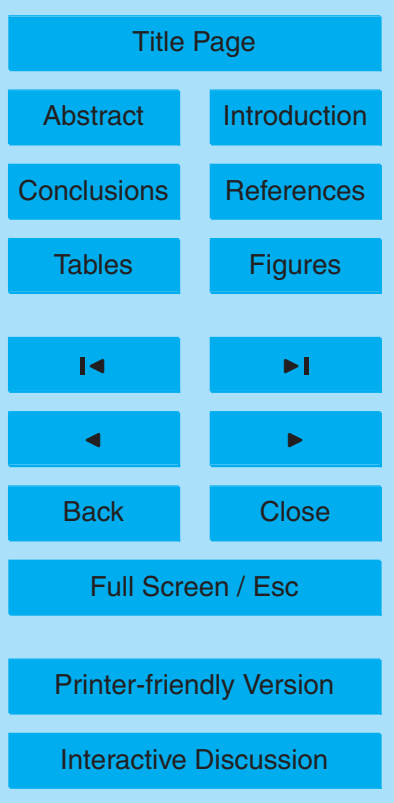


as mentioned in previous publications (Latif and Brimblecombe, 2004, 2005).

\subsection{Surface Tension}

Surface tension analysis was carried out with the pendant drop method using a special needle to create a droplet from aerosol extract. A digital camera (Pulnix TM500) was

5 used in conjunction with a Matrox Meteor frame grabber and Image-Pro Plus (Media Cybernetics, USA) software to determine surface tension based on droplet geometry as mentioned in Latif et al. (2005).

\subsection{Surrogate Acidity}

We used the non-seasalt components (nss) of the aerosol as a surrogate of acid10 ity. This was based on the concentration of $\mathrm{SO}_{4}^{2-}$, and $\mathrm{NO}_{3}^{-}$from the data of Latif et al. (2005) and estimated from the sum: $2 \mathrm{nss}\left[\mathrm{SO}_{4}^{2-}\right]+\mathrm{nss}\left[\mathrm{NO}_{3}^{-}\right]$

\subsection{Dissolved Organic Carbon}

Total dissolved organic carbon (DOC) in atmospheric aerosols was determined using a Shimadzu TOC-500 carbon analyser. Before analysis, samples were acidified to $\mathrm{pH}$

2 with $\mathrm{HCl}(5 \mathrm{~N})(10 \mu \mathrm{L}$ per $10 \mathrm{~mL}$ samples) and bubbled with nitrogen for $10 \mathrm{~min}$ to eliminate interference from inorganic carbon. Samples $(100 \mu \mathrm{L})$ were directly injected into vertical furnace, filled with platinum-coated silica and oxidised at $700^{\circ} \mathrm{C}$. The $\mathrm{CO}_{2}$ concentration resulting from combustion was analysed by non-dispersived infrared detector.

\subsection{Molecular weight of MBAS and EVAS}

Centrifugal filter devices, Amicon ultra-15 (PL-5), with a nominal molecular weight limit below $5000 \mathrm{Da}(5 \mathrm{~K} \mathrm{Da})$, were used to separate the aerosol extracts. The ultrafiltration

Surfactants in aerosols

M. T. Latif and

P. Brimblecombe

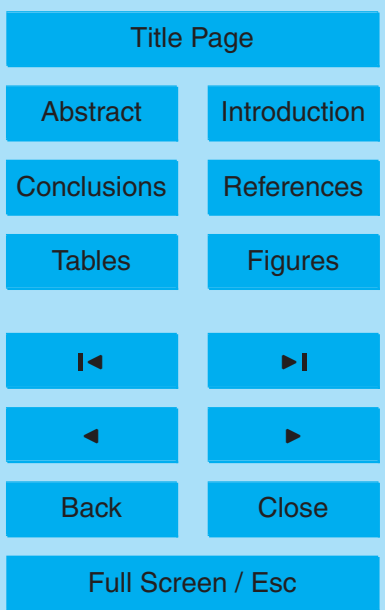

Printer-friendly Version

Interactive Discussion 
set was pre-rinsed using ultra pure water before being used to avoid the effect of trace surfactants within the apparatus.

The aerosol extracts $(15 \mathrm{~mL})$ were spun in a centrifuge (Mistral 1000) at $4000 \times \mathrm{g}$ for thirty minutes. The volume of each aerosol extract after ultrafiltration process was 5 made up to $20 \mathrm{~mL}$ in a volumetric flask before being analysed for MBAS and EVAS (as described in Latif and Brimblecombe, 2005). Part of the extract (10 mL) was used for MBAS analysis and another $(4 \mathrm{~mL})$ was used for EVAS analysis.

\subsection{Molecular weight of the Brown Colourant}

Centrifugal filter devices, Amicon ultra-15 (PL10 and PL30) with different nominal molecular weight limit, $10 \mathrm{~K} \mathrm{Da}$ and $30 \mathrm{~K} \mathrm{Da}$ were used to separate the brown coloured aerosol extracts. The procedures prior to surfactants analysis are as mentioned Sect. 2.1.

\subsection{Ultra violet/visible spectra of yellow-brown extracts}

Ultra violet/visible spectra of the aerosol extracts were determined using a Perkin Elmer 15 UV/Vis spectrometer (Lamda 35) from the range of 200 to $600 \mathrm{~nm}$ wavelength using ultra pure water as a blank.

\subsection{UV Phodegradation}

Aerosol extracts $(20 \mathrm{~mL})$ in quartz samples tube were photodegraded by exposure to a high intensity UV light from a $1000 \mathrm{~W}$ Hanovia mercury lamp for two hours and $24 \mathrm{~h}$.

20 Samples were fan-cooled to maintain a temperature of $50-55^{\circ} \mathrm{C}$. The solutions were analysed for MBAS and EVAS after exposure and compared to concentrations in each solution prior to exposure.

\section{ACPD}

7, 13805-13838, 2007

Surfactants in aerosols

M. T. Latif and

P. Brimblecombe

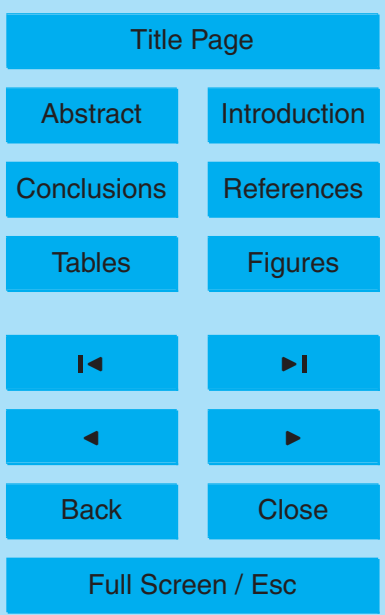

Printer-friendly Version

Interactive Discussion 


\subsection{Soot exposure to ozone}

Dry diesel and petrol soot and humic acid $(50 \mathrm{mg})$ was exposed to ozone in a Dreschel bottle. The ozone was generated from pure oxygen in a laboratory ozoniser, MX II, in the fume cupboard. The flow rate of ozone from the ozone generator was controlled at

51 I per minute, which gave a concentration in the solution of $20 \mathrm{~g} \mathrm{~L}^{-1}$. The extracts were shaken and filtered using $0.2 \mu \mathrm{m} 47 \mathrm{~mm}$ cellulous acetate filter papers (Whatman) and a vacuum pump. Concentrations of MBAS and EVAS in the extracts were analysed as described in Latif and Brimblecombe (2004).

\section{Results and discussion}

\section{3.1 Surface tension of aerosol extracts}

Measurements of surface tension within the pendant drops generated from aerosols both in fine mode and coarse mode aerosol extracts was below 72 dyne $\mathrm{cm}^{-1}$, which indicates that there are present surfactants in the aerosols (Fig. 1a and Fig. 1b). These new measurements add to earlier results reported by Facchini et al. (2000); Tucker15 mann and Cammenga (2004). We see that the reduction in surface tension is most notable with the extracts from fine mode aerosols (aerosol with diameter size $<1.5 \mu \mathrm{m}$ ). The surface tension of the pendant drop generated from fine aerosol extracts significantly reduces with time as surfactant accumulates on the surface.

\subsection{Correlation with surogate acidity}

20 Results indicated that the concentration of MBAS and EVAS (Fig. 2a and Fig. 2b) were influenced by the surrogate acidity of aerosol extracts. The estimates of surrogate acidity concentration in aerosols samples collected in Malaysia as can be seen Fig. 3a and Fig. $3 b$ indicating a strong correlation (MBAS: $n=28, r=0.68$; EVAS: $n=28, r=0.84$ ) with anionic surfactants as MBAS and EVAS. This suggests that acidic pollutants that

Surfactants in aerosols

M. T. Latif and

P. Brimblecombe

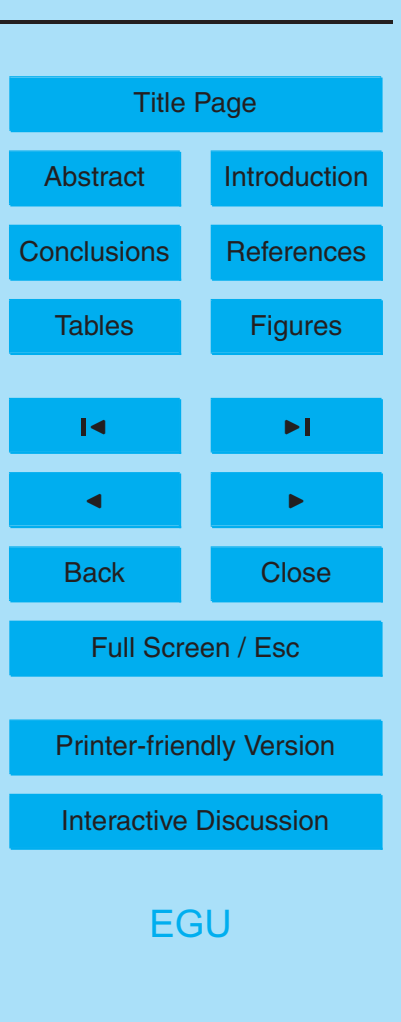


are likely to come from combustion activities, especially motor vehicles and biomass burning around these sampling stations are related to the surfactants.

\subsection{Correlation to Dissolved Organic Carbon (DOC)}

The results of correlation between anionic surfactants as MBAS and EVAS, and DOC 5 in aerosols are shown in Fig. $4 a$ and Fig. 4b. Overall MBAS in coarse mode aerosols $(n=39, r=0.35, p<0.05)$ and fine mode aerosols $(n=39, r=0.56, p<0.05)$ have significant correlation with DOC. The significant correlation also found between EVAS and DOC ( $n=39, r=0.57, p<0.05$ for coarse mode and $n=39, r=0.63, p<0.05$ for fine mode). The correlation between anionic surfactants as MBAS and EVAS, and DOC found in this study reaffirm the relationship between anionic surfactants and DOC indicated in previous studies e.g. Capel et al. (1990) and Facchini et al. (2000) using other methodologies such as a comparison between DOC and surface tension of cloud and wet aerosols.

These overall relationships expressed by the correlations in our data may conceal some important detail embedded there. The linearity is clearer at higher concentrations than at low concentrations, although difficult to see among the scatter of points. At low concentration the relationship may have almost zero slope. It could be that surfactant only begins to appear in the aerosol system after DOC concentrations exceed $100 \mathrm{nmol} \mathrm{m}^{-3}$. Linear regression of the data at higher DOC concentrations suggests 20 a slope of $1.0 \times 10^{-3}$ for MBAS and $4.0 \times 10^{-3}$ for EVAS aerosols. These slopes that suggest less than a one molecule of surfactant (as MBAS) is present for every one thousand dissolved organic carbon atoms and one molecule of surfactant (as EVAS) is present for every two hundred and fifty carbon atoms.

\subsection{Nominal molecular weight of surfactants molecules}

25 The concentration of surfactants after ultrafiltration of fine mode aerosols collected at UEA Norwich are summarised in Fig. 5. Overall, the concentration of MBAS and EVAS

Surfactants in aerosols

M. T. Latif and

P. Brimblecombe

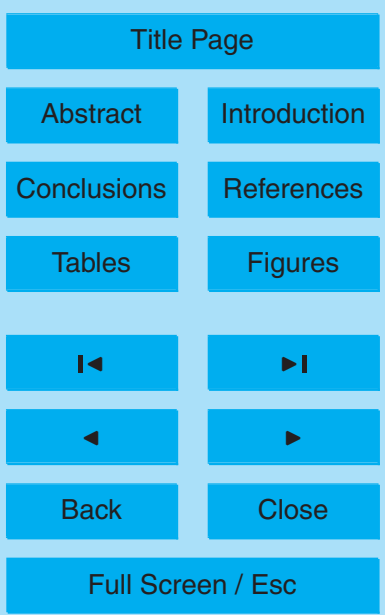

Printer-friendly Version

Interactive Discussion 
in aerosols was found higher in the smaller molecular size range $(<5 \mathrm{~K} \mathrm{Da})$. Several studies have correlated the concentration of atmospheric surface tension with water soluble organic compounds (WSOC) (Bower et al., 2000; Tuckermann and Cammenga, 2004). The distribution of water soluble organic compounds in atmospheric aerosols 5 analysed by Havers et al. (1998) and Zappoli et al. (1999) indicated that the nominal molecular weight of water soluble organic compounds is below $1000 \mathrm{Da}$ and $3070 \mathrm{Da}$ respectively not out of line with the results in this study.

Kiss et al. (2003) in other study estimated the nominal molecular weight of humic like substance in aerosol, which is a possible sources of surfactants in the atmospheric

10 aerosols is around 215-345 Da. The concentration of MBAS after ultrafiltration of $\mathrm{PM}_{10}$ samples collected in Malaysia (Fig. 4) showed the concentration of surfactants also has potential source in compounds with molecular weight above $5 \mathrm{~K} \mathrm{Da}$. On the other hand, the distribution of EVAS concentration after ultrafiltration was still dominated by nominal molecular weight below $5 \mathrm{~K} \mathrm{Da}$. The difference of sampling area background 15 in Europe e.g. the concentration of surfactants of aerosol collected at Great Hungarian Plain (Kiss et al., 2003) which represent rural site and the sampling areas in Malaysia which are more polluted may result in the different findings; particularly the association of surfactants with molecular weights above $5 \mathrm{~K} \mathrm{Da}$.

\subsection{Yellow/Brown colour of aerosol extracts}

20 The spectrophotometric measurements at $400 \mathrm{~nm}$ wavelength correlated with the concentration of surfactants as MBAS $(r=0.83)$ and EVAS $(r=0.76)$ as shown in Fig. 6a and Fig. $6 \mathrm{~b}$. This is much in line with the loose association of perceived colour and amount of dissolved organic material. The intense brown colour of aerosols extracts from samples collected in Malaysia stations also gave a significant correlation $(p<0.05)$ 25 between brown colour and MBAS $(r=0.84)$ and also EVAS $(r=0.73)$. This brown colour was mentioned long ago by Mukai and Ambe (1986) and more recently by Facchini et al. (1999) and was related to a strong ability to act as macromolecular carrying polar group or surfactant in atmospheric aerosols. The relation shown here between brown

\section{Surfactants in} aerosols

M. T. Latif and

P. Brimblecombe

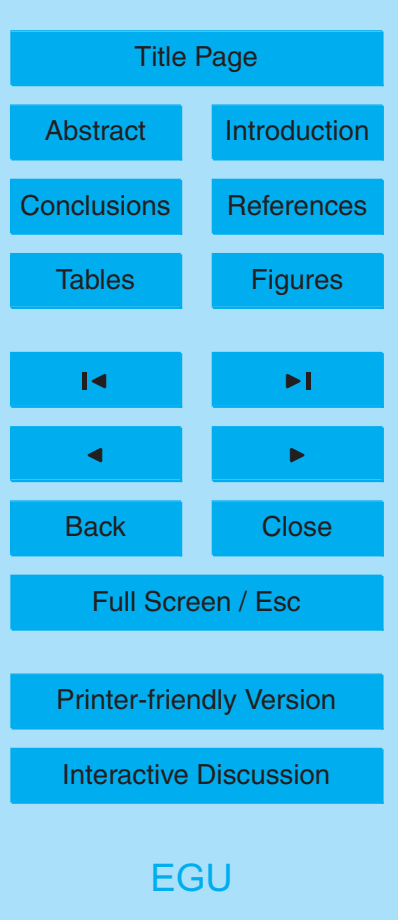


colour and surface activity is a supportive of the importance of HULIS as a surfactant. This is especially true when we note the suggestion from Graber and Rudich (2005) of the association of HULIS with surface tension.

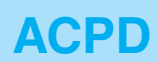

\subsubsection{Exposure to UV light}

5 Exposure of aerosol extracts from the UEA samples shows almost all MBAS in the solution decomposed after $2 \mathrm{~h}$ UV exposure (below $10 \%$ left), but there was around $20 \%$ EVAS still in the solution after such exposures (Fig. 7). Repetition of UV exposure with longer exposure times $(24 \mathrm{~h})$ also gave the same results. Exposure of aerosols extracts collected in Malaysia to UV light also indicated a loss of almost all MBAS while about 10 to $20 \%$ EVAS still remained. In parallel the exposure to UV light caused a loss of yellow/brown colour. The small fraction of EVAS that is resistant to destruction by UV light may arise from inorganic materials, perhaps one of the interferents noted by those who use this reagent in analysis (Latif and Brimblecombe, 2004).

\subsubsection{Separation of "brown" aerosol extracts using ultrafiltration}

15 The intensity of the brown colour of aerosol extracts declined after ultrafiltration with $30 \mathrm{~K} \mathrm{Da}$ and $10 \mathrm{~K} \mathrm{Da}$, but it not necessarily decreased the concentration of surfactants significantly especially for EVAS as shown in Fig. 8, so not all brown HULIS is surfactant. The UV-Vis spectra of the extracts after ultrafiltration (Fig. 9) with both molecular sized filters show this reduction. The absorbance of the two ultrafiltered extracts of aerosol extracts are similar at about 0.2 for $300 \mathrm{~nm}$, suggesting that both the high and low molecular weight HULIS components are coloured.

\subsection{Characteristic of possible sources of atmospheric surfactants}

Based on our early studies, Latif and Brimblecombe (2004), anionic surfactants determined as MBAS and EVAS were found in soot e.g. diesel and petrol soot and have similar characteristic to humic like substances. The amount of surfactant present on

Surfactants in aerosols

M. T. Latif and

P. Brimblecombe

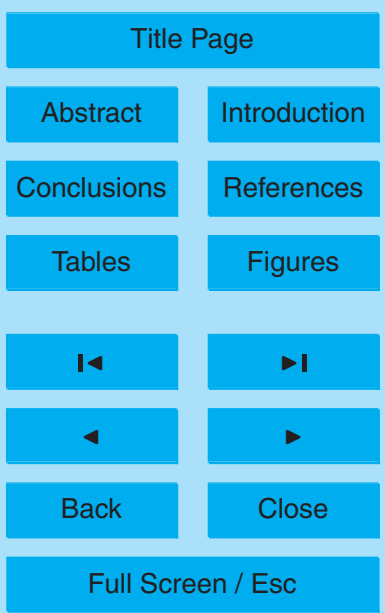

Printer-friendly Version

Interactive Discussion 
these possible sources tended to be enhanced by oxidation e.g. through exposure to ozone and sunlight (Latif and Brimblecombe, 2004). Here we tried to measure the molecular weight of MBAS and EVAS produced by such exposures to ozone.

The molecular weight distribution of surfactants before ozone exposure (white bars) 5 differ among petrol soot, diesel soot and laboratory humic acid (Fig. 10). The distribution of MBAS among the various molecular weight size ranges for laboratory humic acid are found to be quite different from that in petrol and diesel soot (see Fig. 10). Much of this MBAS from humic acid was found in the range of $10 \mathrm{~K}$ to $30 \mathrm{~K}$ Da range compared to a predominance in the smaller molecular weight range $(<5 \mathrm{~K} \mathrm{Da})$ for petrol and diesel 10 soot. This results is well related to the finding of Pierson et al. (1983) which indicated that there was little high molecular weight organic fraction in automotive diesel soot compared to combustion of plants materials (Mukai and Ambe, 1986).

After exposure to ozone (hatched bars) the MBAS in petrol soot and diesel soot was detected in the molecular weight ranges below $10 \mathrm{~K} \mathrm{Da}$. It should be noticed that in Fig. 10a and Fig. 10b the concentrations have increased after ozone exposure both petrol suggesting the production of MBAS below $10 \mathrm{~K} \mathrm{Da}$. The MBAS found in laboratory humic acid was initially found in the higher molecular weight ranges (10 K to $30 \mathrm{~K} \mathrm{Da}$ ), but decreased noticeably on exposure to ozone (Fig. 10c).

The concentration of surfactants as EVAS in soot and humic acid before and af20 ter ozone exposure is shown in Fig. 11. These concentrations are somewhat higher that those found for MBAS, which is also typical of aerosol measurements in the atmosphere (Latif and Brimblecombe, 2004). The EVAS is almost entirely found at low molecular weights $(<5 \mathrm{~K} \mathrm{Da})$ in petrol soot, diesel soot and humic acid solution. These results are quite same to the concentration of EVAS in aerosols extract which found 25 higher in the solution with molecular weight below than $5 \mathrm{~K}$. After ozone exposure the amount of EVAS in the low molecular weight fraction increased, suggestion it was produced on the aerosol, except in the case of diesel soot.

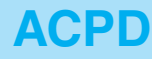

7, 13805-13838, 2007

\section{Surfactants in} aerosols

M. T. Latif and

P. Brimblecombe

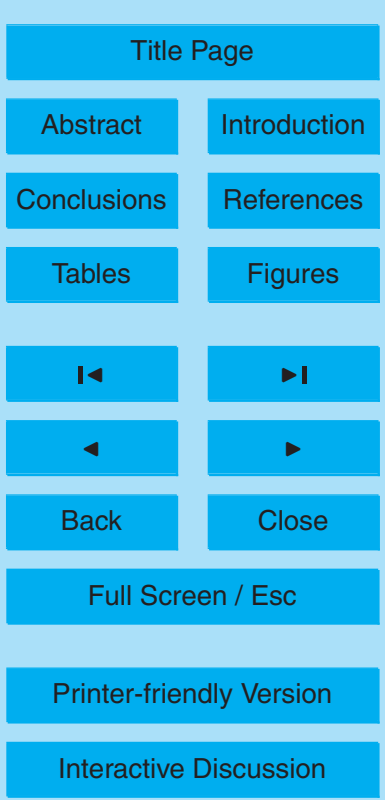




\section{Conclusions}

Comparisons between our work and that of earlier studies reinforce the potential links between the presence of HULIS and brown-yellow colour of aerosol extracts and their surfactant nature. As in the case of earlier work we find the presence of much sur-

5 factant material, especially in the fine mode aerosol, in the molecular size range $<5 \mathrm{~K}$ $\mathrm{Da}$, although in very polluted conditions during haze episodes derived from biomass burning in Malaysia substantial amounts were present at molecular weights above $5 \mathrm{~K}$ Da.

There was a relationship between sulfate and nitrate and the amount of surfactants, 10 which hinted at combustion sources. The was also a relationship with DOC, although hints that this relationship may have been stronger when the amount of DOC was high, where one molecule of surfactant as MBAS seemed to be present for every 1000 atoms of carbon and one moleculr of surfactant as EVAS for every 250 atoms of carbon.

Although our experiments were restricted to relatively high concentrations of ozone $15(20 \mathrm{ppm})$ there was evidence that reactions on soot and humic acid could produce surfactants. The surfactants produces were typically of molecular weight below $5 \mathrm{~K} \mathrm{Da}$. This is in accord with the observation that much HULIS in the atmosphere is present at low molecular weights. While ozone may produce surfactant compounds it might also destroy them under some conditions. Surfactants can be correlated to the brown and organic HULIS but this study also indicate it is not all brown HULIS can be considered as surfactants.

\section{References}

Aitken, G. R., McKnight, D. M., Wershaw, R. L., and MacCarthy, P.: An introduction to humic substances in soil, sediment, and water, in: Humic substances in soil, sediment and water,

\section{Surfactants in} aerosols

M. T. Latif and

P. Brimblecombe

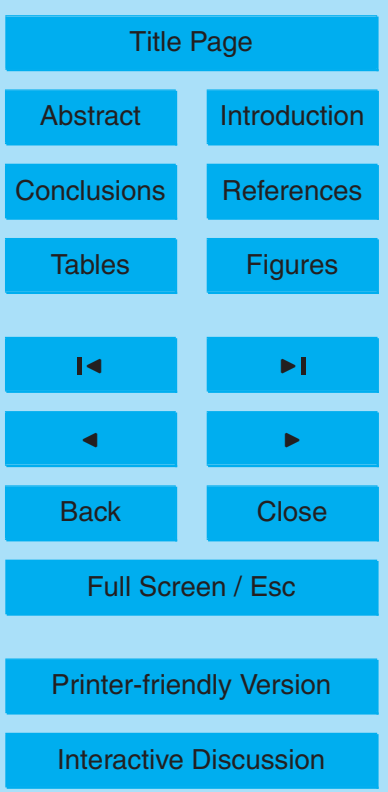


Balasubramanian, R., Qian, W. B., Decesari, S., Facchini, M. C., and Fuzzi, S.: Comprehensive characterization of $\mathrm{PM}_{2.5}$ aerosols in Singapore, J. Geophys. Res.-Atmos., 108, 4523, doi:10.1029/2002JD002517, 2003.

Blanchard, D. C.: Sea-to-Air Transport of Surface Active Material, Science, 146, 396-397, 1964.

Bower, B. K. N., Choularton, T. W., Gallagher, M. W., Beswick, K. M., Flynn, M. J., Allen, A. G., Davison, B. M., James, J. D., Robertson, L., Harrison, R. M., Hewitt, C. N., Cape, J. N., McFadyen, G. G., Milford, C., Sutton, M. A., Martinsson, B. G., Frank, G., Swietlicki, E., Zhou, J., Berg, O. H., Mentes, B., Papaspiropoulos, G., Hansson, H. C., Leck, C., Kulmala, M., Aalto, P., Vakeva, M., Berner, A., Bizjak, M., Fuzzi, S., Laj, P., Facchini, M. C., Orsi, G., Ricci, L., Nielsen, M., Allan, B. J., Coe, H., McFiggans, G., Plane, J. M. C., Collett, J. L., Moore, K. F., and Sherman, D. E.: ACE-2 HILLCLOUD. An overview of the ACE-2 groundbased cloud experiment, Tellus Ser. B-Chem. Phys. Meteorol., 52, 750-778, 2000.

Capel, P. D., Gunde, R., Zurcher, F., and Giger, W.: Carbon Speciation and Surface-Tension of 15 Fog, Environ. Sci. Technol., 24, 722-727, 1990.

Chughtai, A. R., Williams, G. R., Atteya, M. M. O., Miller, N. J., and Smith, D. M.: Carbonaceous particle hydration, Atmospheric Environment, 33, 2679-2687, 1999.

Cini, R. and Loglio, G.: Adsorption and pollutant transport by marine aerosol, Mar. Pollut. Bull., 34, 501-504, 1997.

20 Facchini, M. C., Decesari, S., Mircea, M., Fuzzi, S., and Loglio, G.: Surface tension of atmospheric wet aerosol and cloud/fog droplets in relation to their organic carbon content and chemical composition, Atmospheric Environment, 34, 4853-4857, 2000.

Facchini, M. C., Fuzzi, S., Zappoli, S., Andracchio, A., Gelencser, A., Kiss, G., Krivacsy, Z., Meszaros, E., Hansson, H. C., Alsberg, T., and Zebuhr, Y.: Partitioning of the organic aerosol component between fog droplets and interstitial air, J. Geophys. Res.-Atmos., 104, $26821-$ 26 832, 1999a.

Facchini, M. C., Mircea, M., Fuzzi, S., and Charlson, R. J.: Cloud albedo enhancement by surface-active organic solutes in growing droplets, Nature, 401, 257-259, $1999 \mathrm{~b}$.

Feng, J. S. and Moller, D.: Characterization of water-soluble macromolecular substances in cloud water, J. Atmos. Chem., 48, 217-233, 2004.

Gilman, J. B., Eliason, T. L., Fast, A., and Vaida, V.: Selectivity and stability of organic films at the air-aqueous interface, Journal of Colloid and Interface Science, 280, 234-243, 2004.

Giovannelli, G., Bonasoni, P., Loglio, G., Ricci, C., Tesei, U., and Cini, R.: Evidence of Anionic-

Surfactants in aerosols

M. T. Latif and

P. Brimblecombe

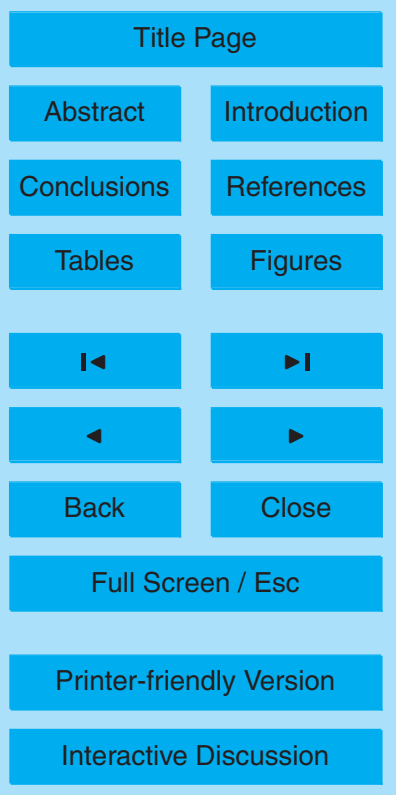


Surfactant Enrichment in Marine Aerosol, Marine Pollution Bulletin, 19, 274-277, 1988.

Graber, E. R. and Rudich, Y.: Atmospheric HULIS: how humic-like are they? A comprehensive and critical review, Atmos. Chem. Phys., 5, 9801-9860, 2005,

http://www.atmos-chem-phys.net/5/9801/2005/.

5 Havers, N., Burba, P., Lambert, J., and Klockow, D.: Spectroscopic characterization of humiclike substances in airborne particulate matter, J. Atmos. Chem., 29, 45-54, 1998.

Kiss, G., Tombacz, E., Varga, B., Alsberg, T., and Persson, L.: Estimation of the average molecular weight of humic-like substances isolated from fine atmospheric aerosol, Atmos. Environ., 37, 3783-3794, 2003.

10 Krivacsy, Z., Kiss, G., Varga, B., Galambos, I., Sarvari, Z., Gelencser, A., Molnar, A., Fuzzi, S., Facchini, M. C., Zappoli, S., Andracchio, A., Alsberg, T., Hansson, H. C., and Persson, L.: Study of humic-like substances in fog and interstitial aerosol by size-exclusion chromatography and capillary electrophoresis, Atmos. Environ., 34, 4273-4281, 2000.

Latif, M. T. and Brimblecombe, P.: Surfactants in atmospheric aerosols, Environ. Sci. Technol., 15 38, 6501-6506, 2004.

Latif, M. T., Brimblecombe, P., Ramli, N. A., Sentian, J., Sukhapan, J., and Sulaiman, N.: Surfactants in South East Asian Aerosols, Environ. Chem., 2, 198-204, 2005.

Loglio, G., Tesei, U., Marilli, G., and Cini, R.: The role of surfactants in coastal sea pollution, Mar. Pollut. Bull., 17, 466-468, 1986.

20 Loglio, G., Tesei, U., Mori, G., Cini, R., and Pantani, F.: Enrichment and transport of surfactants in marine aerosol formed during particular weather conditions, Nuovo Cimento Soc. Ital. Fis. C-Geophys. Space Phys., 8, 704-713, 1985.

Mezaros, E., Barcza, T., Gelencser, A., Hlavay, J., Kiss, G., Krivacsy, Z., Molnar, A., and Polyak, K.: Size distribution of inorganic and organic and organic species in the atmospheric aerosols in Hungary, J. Aerosol Sci., 28, 1163-1175, 1997.

Mukai, $\mathrm{H}$. and Ambe, Y.: Characterization of a humic acid-like brown substance in airborne particulate matter and tentative Identification of its origin, Atmos. Environ., 20, 813-819, 1986.

Nicolotti, G., Rettori, A., Paoletti, E., and Gullino, M. L.: Morphological and physiological damage by surfactant-polluted seaspray on Pinus pinea and Pinus halepensis, Environmental Monitoring and Assessment, 105, 175-191, 2005.

Oppo, C., Bellandi, S., Innocenti, N. D., Stortini, A. M., Loglio, G., Schiavuta, E., and Cini, R.: Surfactant components of marine organic matter as agents for biogeochemical fractionation

\section{Surfactants in aerosols}

M. T. Latif and

P. Brimblecombe

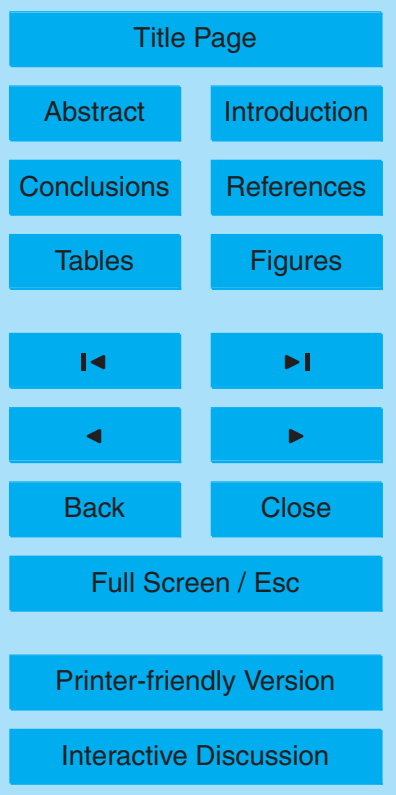


and pollutant transport via marine aerosols, Mar. Chem., 63, 235-253, 1999.

Peterson, R. E. and Tyler, B. J.: Analysis of organic and inorganic species on the surface of atmospheric aerosol using time-of-flight secondary ion mass spectrometry (TOF-SIMS), Atmos. Environ., 36, 6041-6049, 2002.

5 Peterson, R. E. and Tyler, B. J.: Surface composition of atmospheric aerosol: individual particle characterization by TOF-SIMS, Applied Surface Science, 203, 751-756, 2003.

Pierson, W. R., Gorse, R. A., Szkarlat, A. C., Brachaczek, W. W., Japar, S. M., Lee, F. S. C., Zweidinger, R. B., and Claxton, L. D.: Mutagenicity and Chemical Characteristics of Carbonaceous Particulate Matter from Vehicles on the Road, Environ. Sci. Technol., 17, $10 \quad 31-44,1983$.

Rettori, A., Paoletti, E., Nicolotti, G., and Gullino, M. L.: Ecophysiological responses of Mediterranean pines to simulated sea aerosol polluted with an anionic surfactant: prospects for biomonitoring, Ann. Forest Sci., 62, 351-360, 2005.

Samburova, V., Kalberer, M., and Zenobi, R.: Characterization of high molecular weight com15 pounds in urban atmospheric particles, Atmos. Chem. Phys. Discuss., 5, 437-454, 2005, http://www.atmos-chem-phys-discuss.net/5/437/2005/.

Sukhapan, J. and Brimblecombe, P.: Ionic surface active compound in atmospheric aerosol, The Scientific World Journal, 2, 1138-1146, 2002.

Tervahattu, H., Hartonen, K., Kerminen, V. M., Kupiainen, K., Aarnio, P., Koskentalo, T., Tuck, 20 A. F., and Vaida, V.: New evidence of an organic layer on marine aerosols, J. Geophys. Res.-Atmos., 107, 4053, doi:10.1029/2000JD000282, 2002a.

Tervahattu H., Juhanoja, J., and Kupiainen, K.: Identification of an organic coating on marine aerosol particles by TOF-SIMS, J. Geophys. Res.-Atmos., 107, 4319, doi:10.1029/2001JD001403, 2002b.

Tervahattu, H., Juhanoja, J., Vaida, V., Tuck, A. F., Niemi, J. V., Kupiainen, K., Kulmala, M., and Vehkamaki, H.: Fatty acids on continental sulfate aerosol particles, J. Geophys. Res.-Atmos., 110, D06207, doi:10.1029/2004JD005400, 2005.

Tuckermann, R. and Cammenga, H. K.: The surface tension of aqueous solutions of some atmospheric water-soluble organic compounds, Atmos. Environ., 38, 6135-6138, 2004.

30 Weingartner, E., Burtscher, H., and Baltensperger, U.: Hygroscopic properties of carbon and diesel soot particles, Atmos.c Environ., 31, 2311-2327, 1997.

Went, F. W.: Blue Hazes in the Atmosphere, Nature, 187, 641-643, 1960.

Yates, L. M. I. and Wandruszka, R. V.: Effect of $\mathrm{pH}$ and metals on the surface tension aqueous

Surfactants in aerosols

M. T. Latif and

P. Brimblecombe

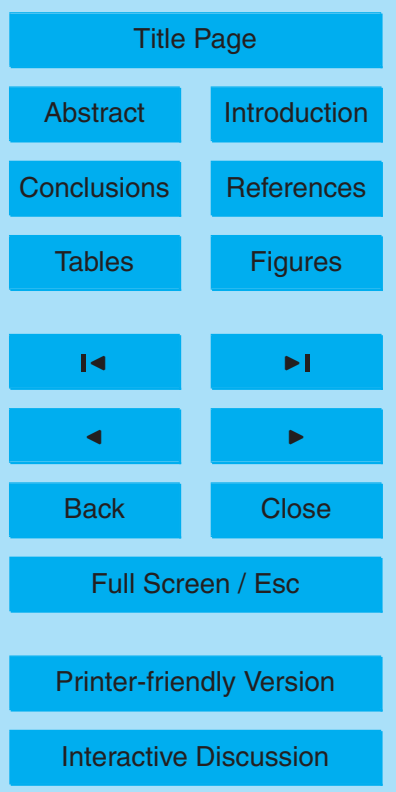

EGU 
humic materials, Soil Sci. Soc. Am. J., 63, 1645-1649, 1999.

Zappoli, S., Andracchio, A., Fuzzi, S., Facchini, M. C., Gelencser, A., Kiss, G., Krivacsy, Z., Molnar, A., Meszaros, E., Hansson, H. C., Rosman, K., and Zebuhr, Y.: Inorganic, organic and macromolecular components of fine aerosol in different areas of Europe in relation to their water solubility, Atmos. Environ., 33, 2733-2743, 1999.

\section{ACPD}

7, 13805-13838, 2007

\section{Surfactants in} aerosols

M. T. Latif and

P. Brimblecombe

Title Page

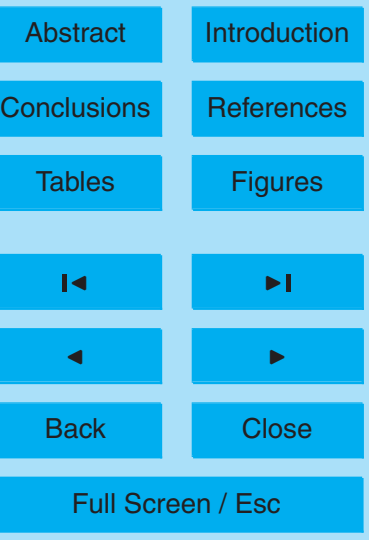

Printer-friendly Version

Interactive Discussion 


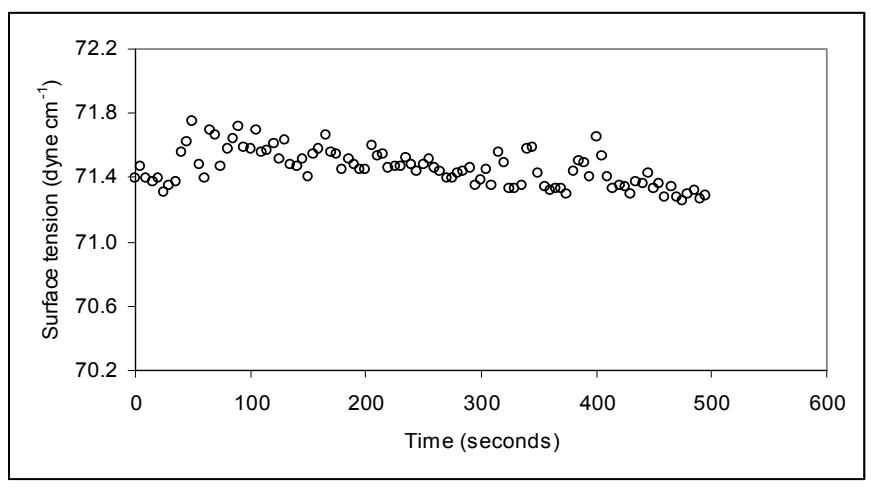

\section{ACPD}

7, 13805-13838, 2007

\section{Surfactants in} aerosols

M. T. Latif and

P. Brimblecombe

(a) Coarse mode aerosol

Title Page

Abstract

Introduction

Conclusions

References

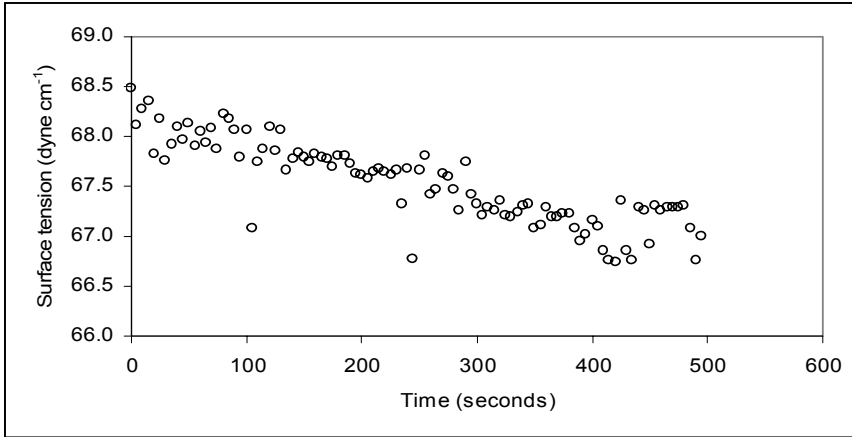

Tables

Figures

14

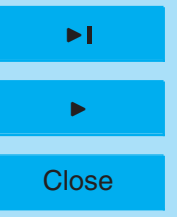

\section{Back}

Close

\section{Full Screen / Esc}

Printer-friendly Version

Fig. 1. The changing of surface tension of the pendant drop by time.

Interactive Discussion 


\section{ACPD}

7, 13805-13838, 2007

\section{Surfactants in} aerosols

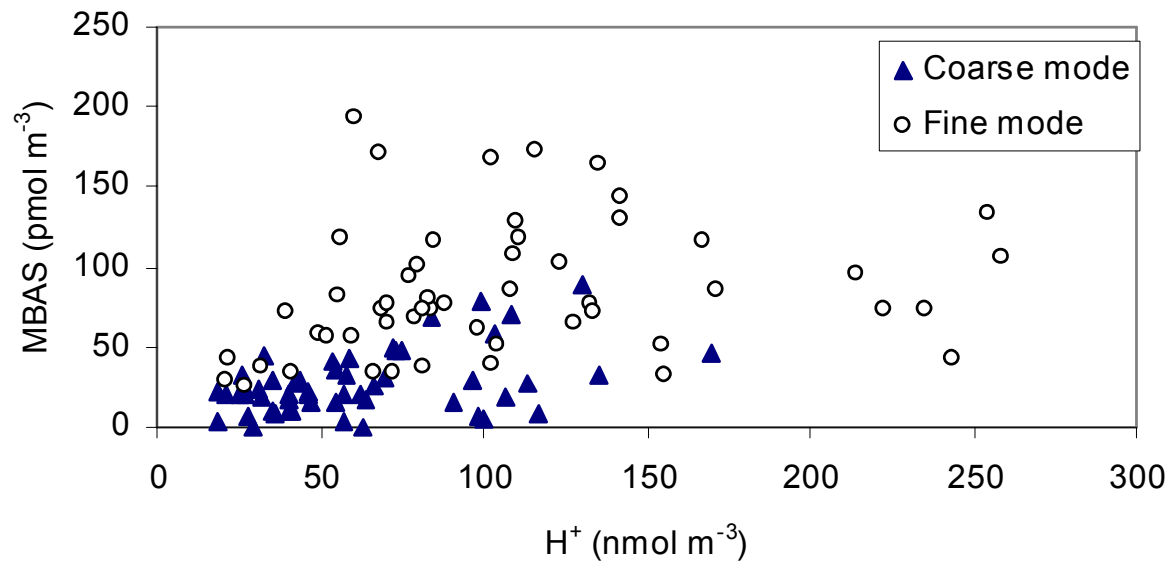

M. T. Latif and

P. Brimblecombe

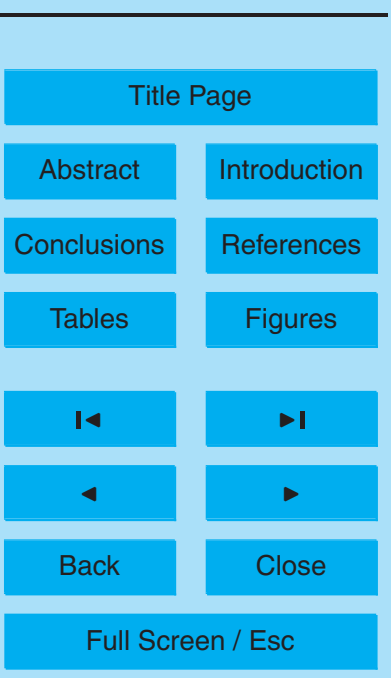

Printer-friendly Version

Interactive Discussion 


\section{ACPD}

7, 13805-13838, 2007

\section{Surfactants in} aerosols

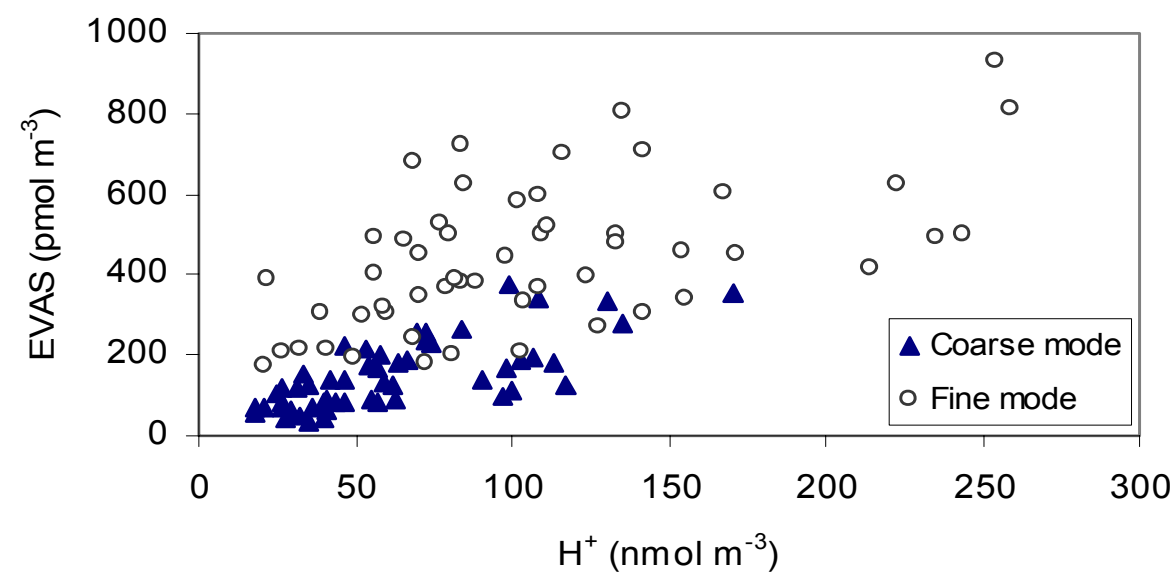

M. T. Latif and

P. Brimblecombe

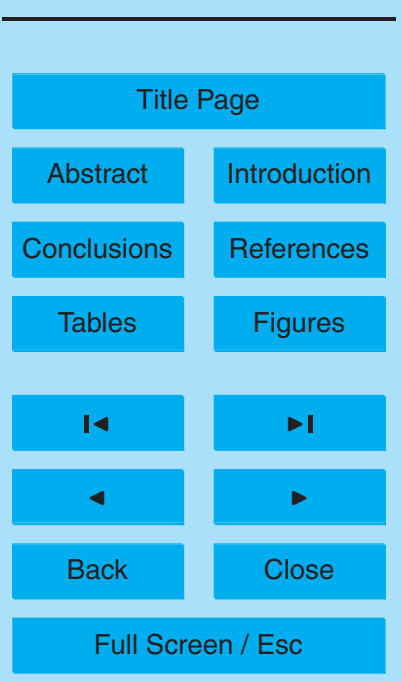

Printer-friendly Version

Interactive Discussion 


\section{ACPD}

7, 13805-13838, 2007

\section{Surfactants in} aerosols

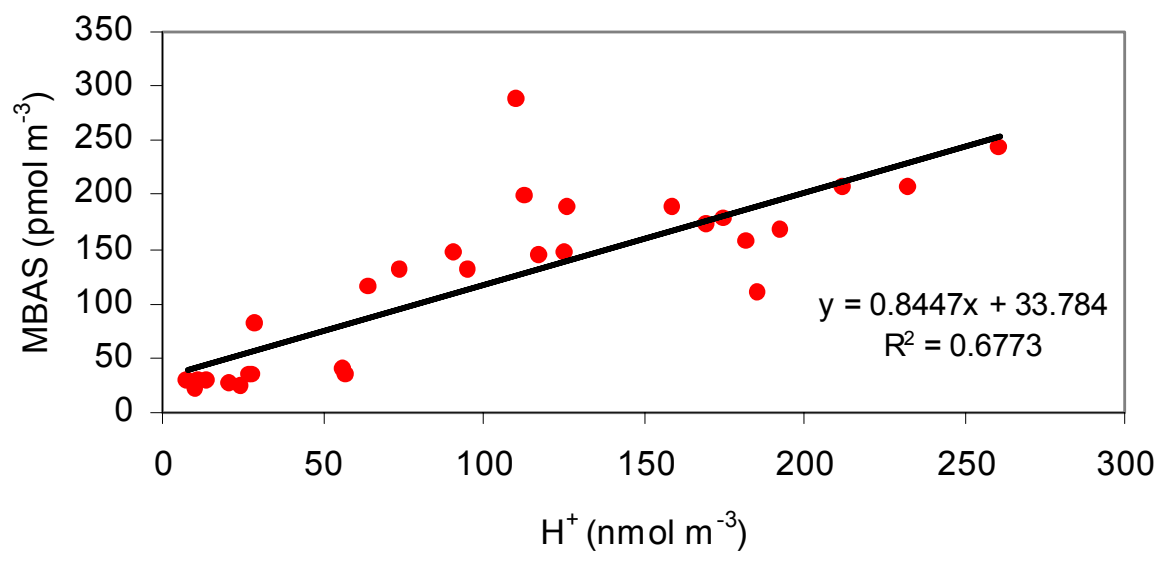

M. T. Latif and

P. Brimblecombe

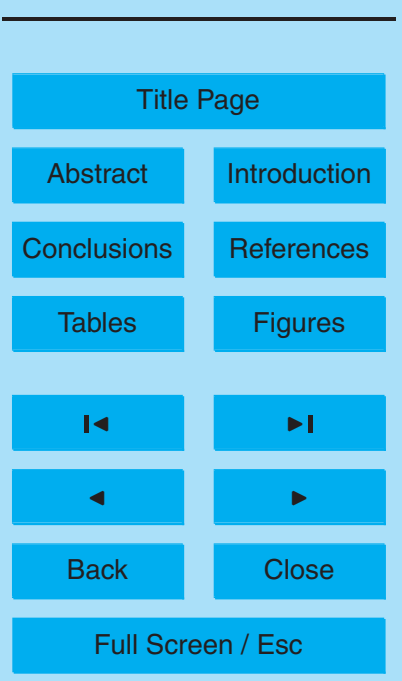

Printer-friendly Version

Fig. 3a. Concentration of MBAS compared to free $\mathrm{H}^{+}$in aerosols collected in all sampling stations in Malaysia.

Interactive Discussion 


\section{ACPD}

7, 13805-13838, 2007

\section{Surfactants in} aerosols

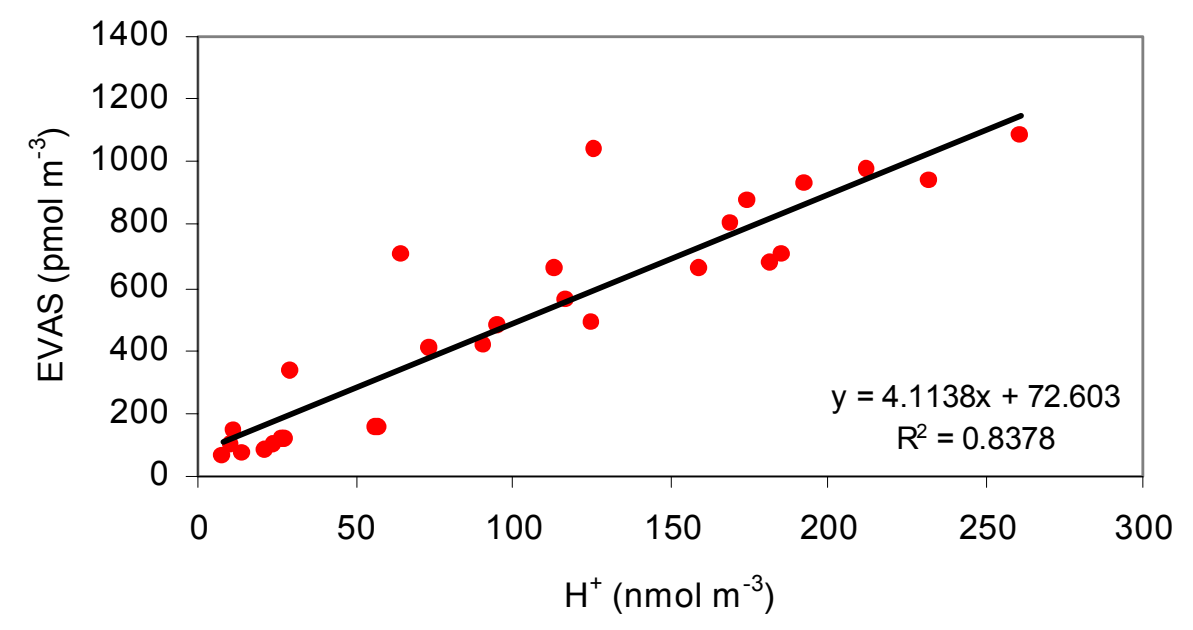

Fig. 3b. Concentration of EVAS compared to free $\mathrm{H}^{+}$in aerosols collected in all sampling stations in Malaysia.
M. T. Latif and

P. Brimblecombe

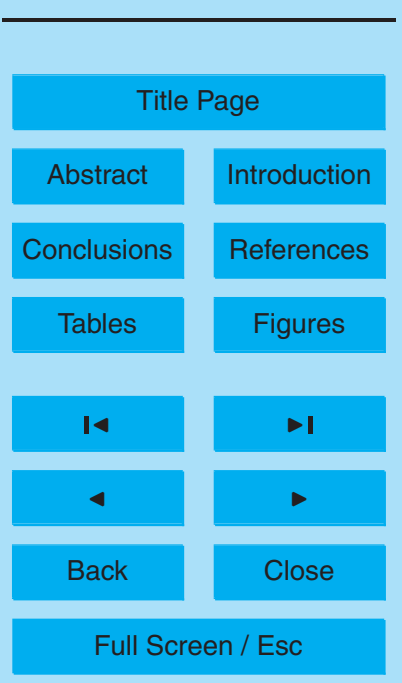

Printer-friendly Version

Interactive Discussion 


\section{ACPD}

7, 13805-13838, 2007

\section{Surfactants in} aerosols

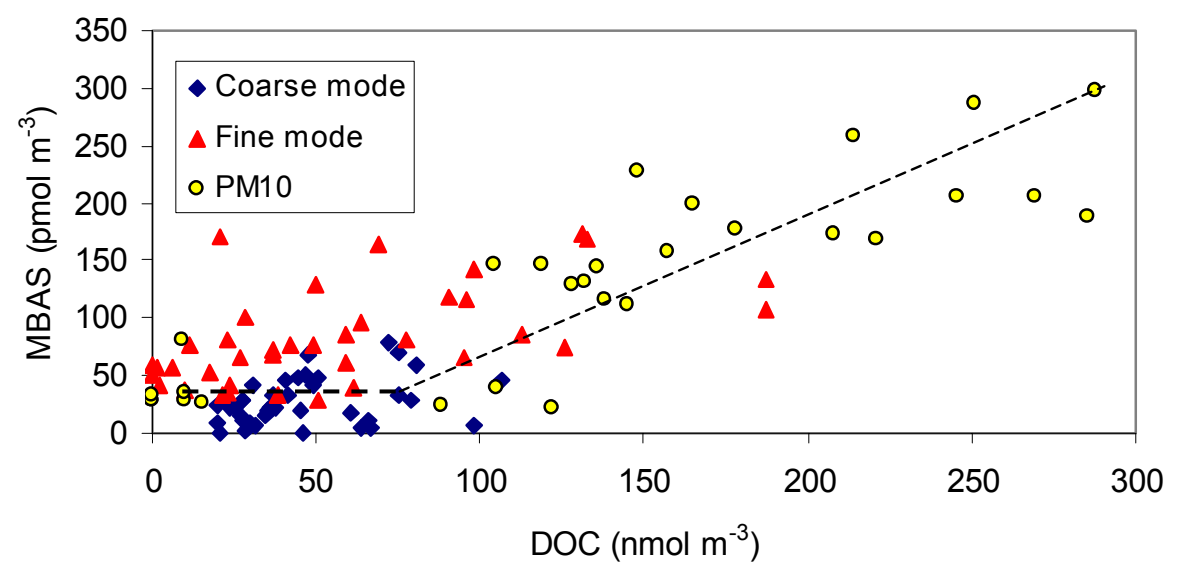

M. T. Latif and

P. Brimblecombe

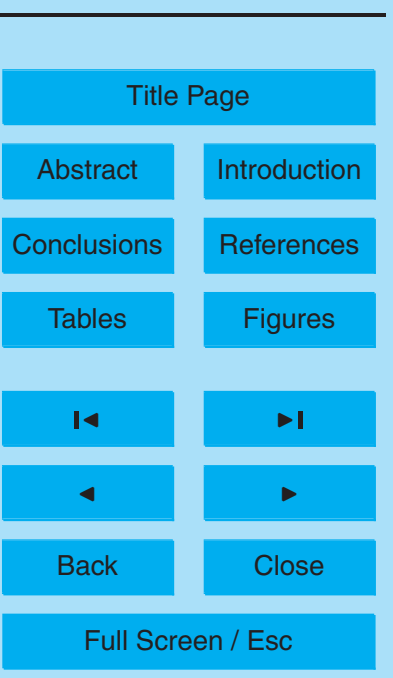

Printer-friendly Version

Interactive Discussion 


\section{ACPD}

7, 13805-13838, 2007

\section{Surfactants in} aerosols

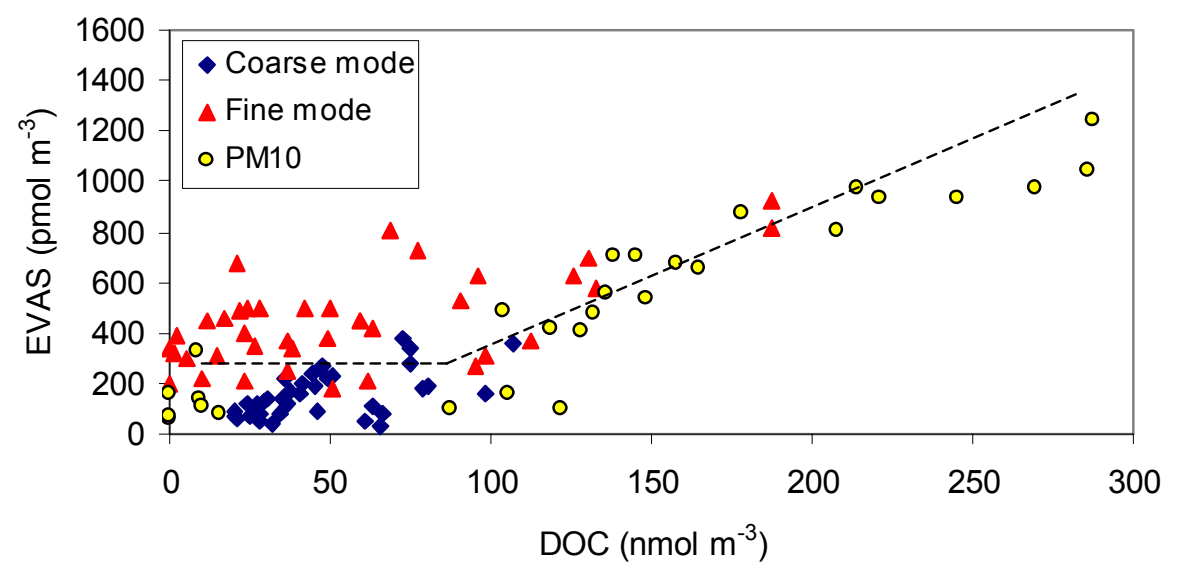

M. T. Latif and

P. Brimblecombe

Fig. 4b. Concentration of EVAS compared to DOC in aerosols collected at UEA (as fine and coarse) and Malaysia (Bangi, Penang and Kota Kinabalu).

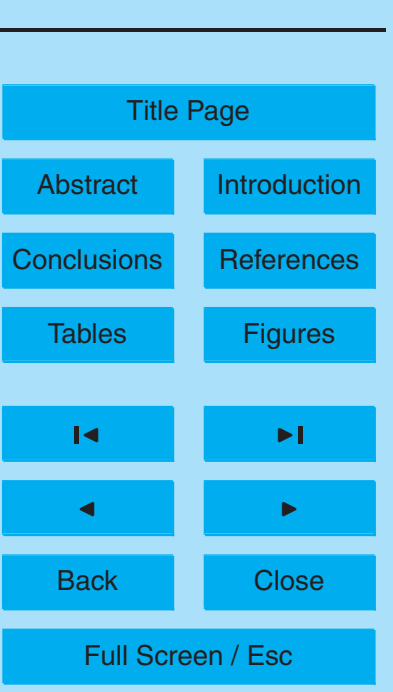

Printer-friendly Version

Interactive Discussion 


\section{ACPD}

7, 13805-13838, 2007

\section{Surfactants in} aerosols

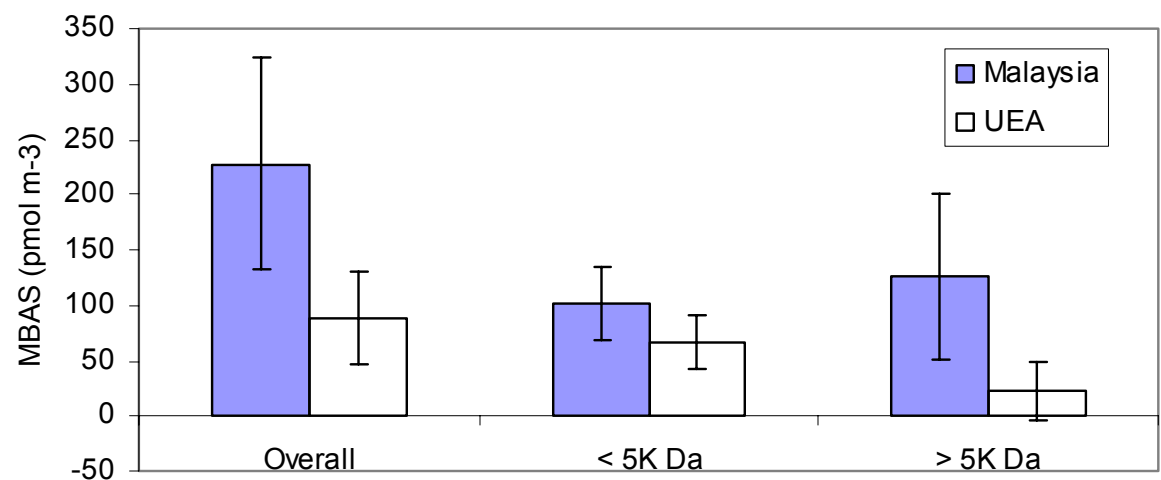

Nominal Molecular Weight

Fig. 5a. Distribution of MBAS in fine mode aerosols samples collected at UEA and $\mathrm{PM}_{10}$ in Malaysia (Bangi, Penang and Kota Kinabalu) based on nominal molecular weight.
M. T. Latif and

P. Brimblecombe

Title Page

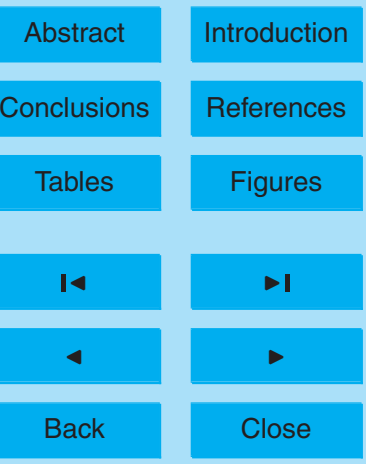

Full Screen / Esc

Printer-friendly Version

Interactive Discussion 


\section{ACPD}

7, 13805-13838, 2007

\section{Surfactants in} aerosols

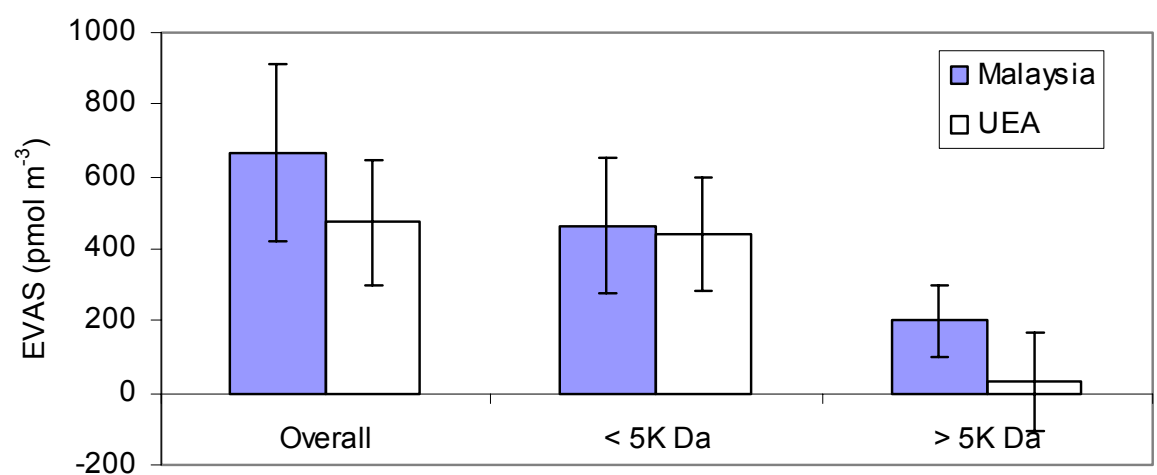

Nominal Molecular Weight

Fig. 5b. Distribution EVAS in fine mode aerosols samples collected at UEA and $\mathrm{PM}_{10}$ in Malaysia (Bangi, Penang and Kota Kinabalu) based on nominal molecular weight.
M. T. Latif and

P. Brimblecombe

Title Page

Abstract

Introduction

Conclusions

References

Tables

Figures

14

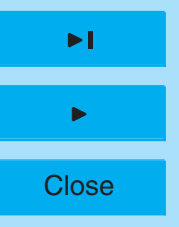

Back

Close

Full Screen / Esc

Printer-friendly Version

Interactive Discussion 


\section{ACPD}

$7,13805-13838,2007$

\section{Surfactants in} aerosols

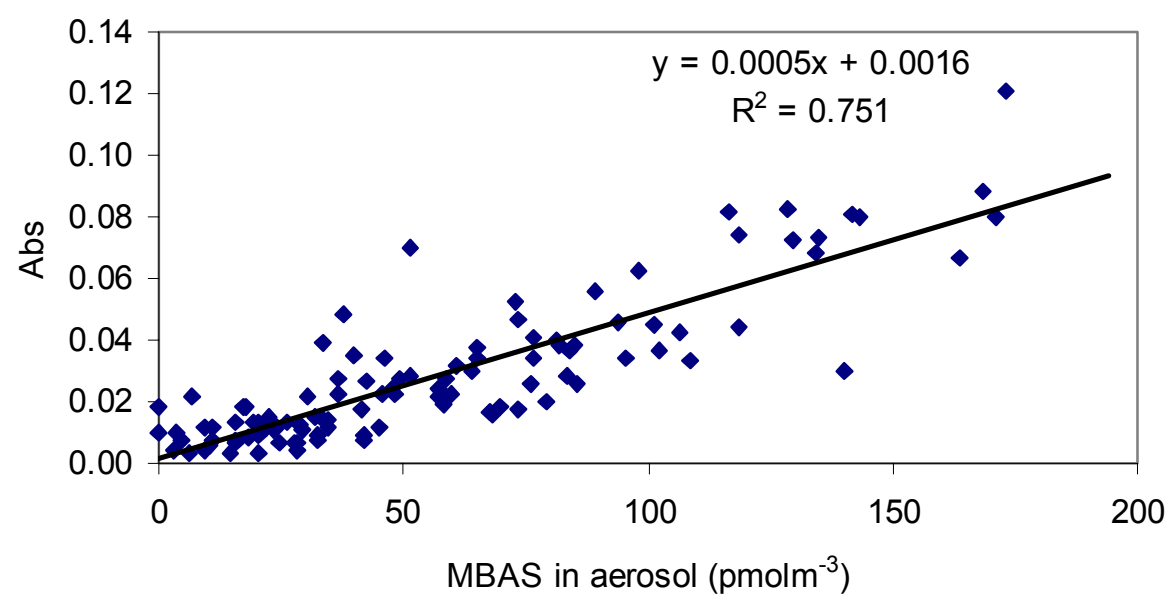

Fig. 6a. Absorbance of aerosol extracts (UEA, Norwich) at $400 \mathrm{~nm}$ as a function of MBAS concentration.

M. T. Latif and

P. Brimblecombe

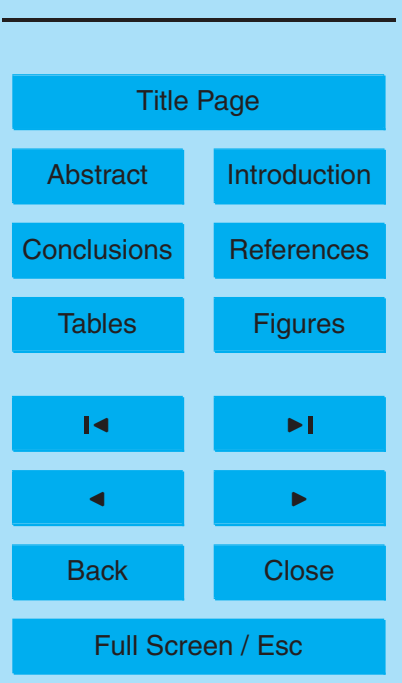

Printer-friendly Version

Interactive Discussion 


\section{ACPD}

7, 13805-13838, 2007

\section{Surfactants in} aerosols

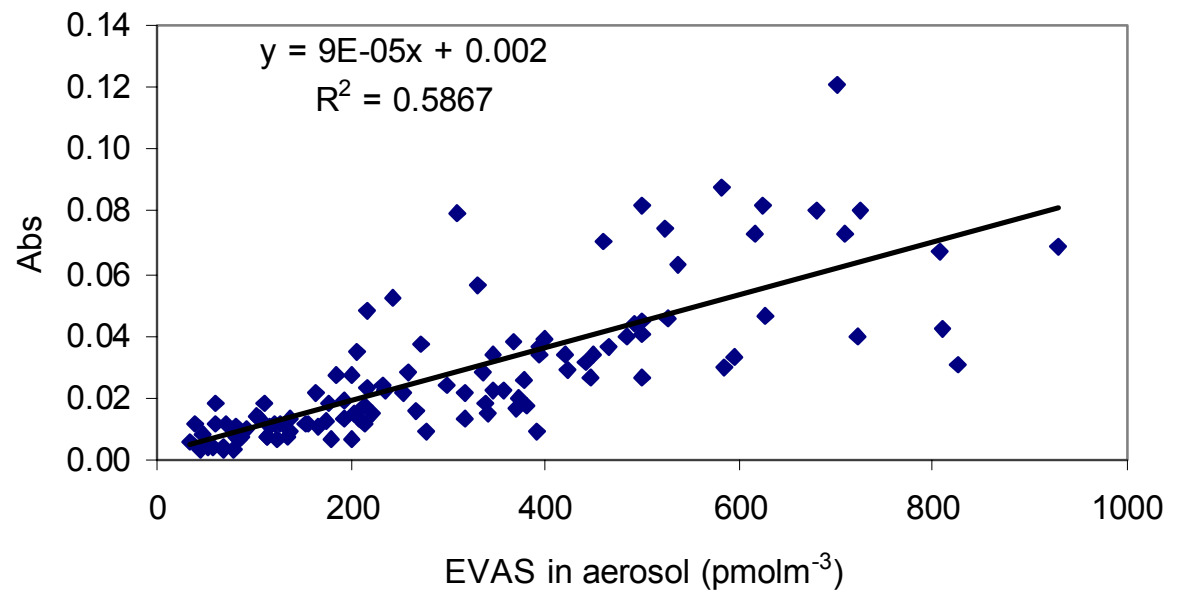

Fig. 6b. Absorbance of aerosol extracts (UEA, Norwich) at $400 \mathrm{~nm}$ as a function of EVAS concentration.

\section{T. Latif and}

P. Brimblecombe

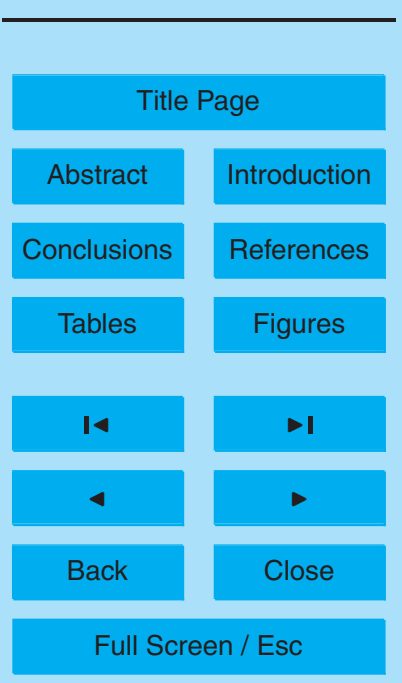

Printer-friendly Version

Interactive Discussion 


\section{ACPD}

7, 13805-13838, 2007

\section{Surfactants in} aerosols

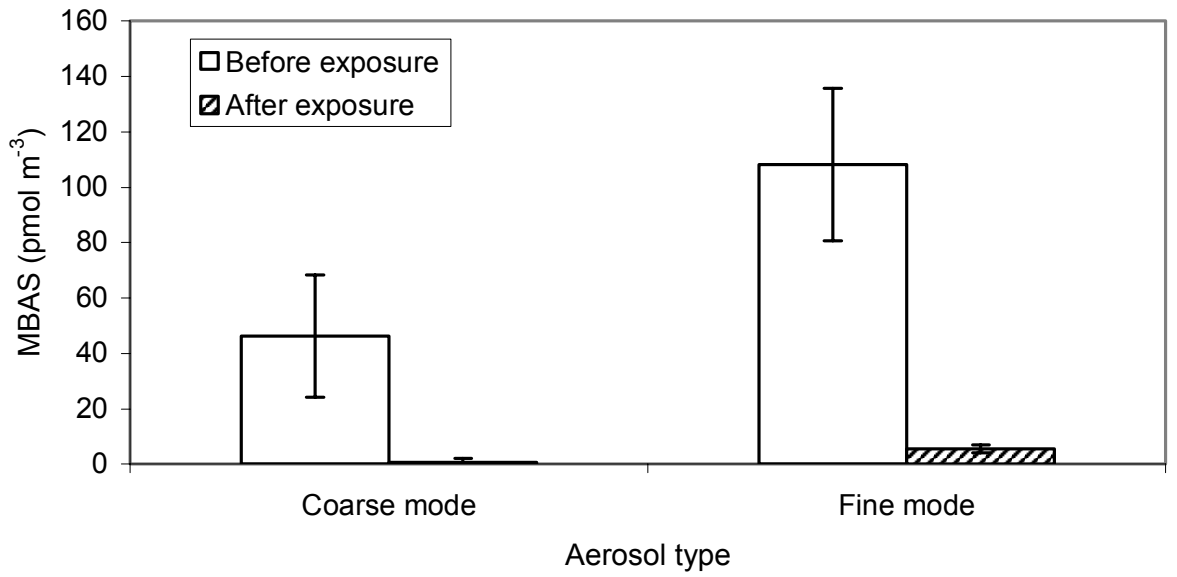

M. T. Latif and

P. Brimblecombe

Title Page

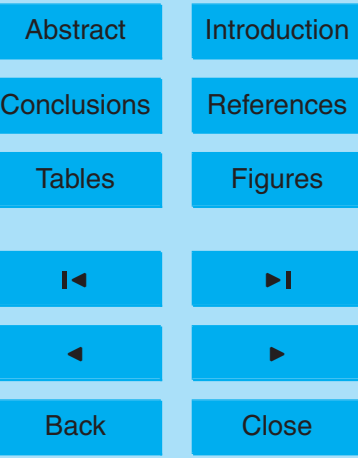

Full Screen / Esc

Fig. 7a. Concentration of MBAS in coarse and fine mode aerosols before and after UV light exposure. 


\section{ACPD}

7, 13805-13838, 2007

\section{Surfactants in} aerosols

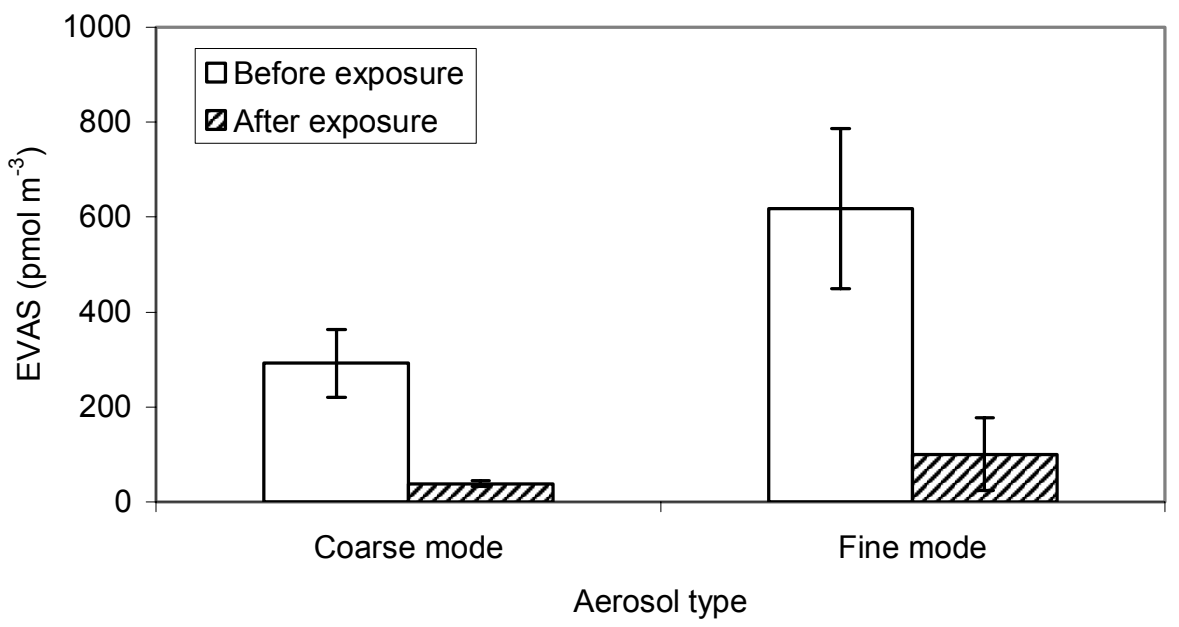

Fig. 7b. Concentration of EVAS in coarse and fine mode aerosols before and after UV light exposure.

M. T. Latif and

P. Brimblecombe

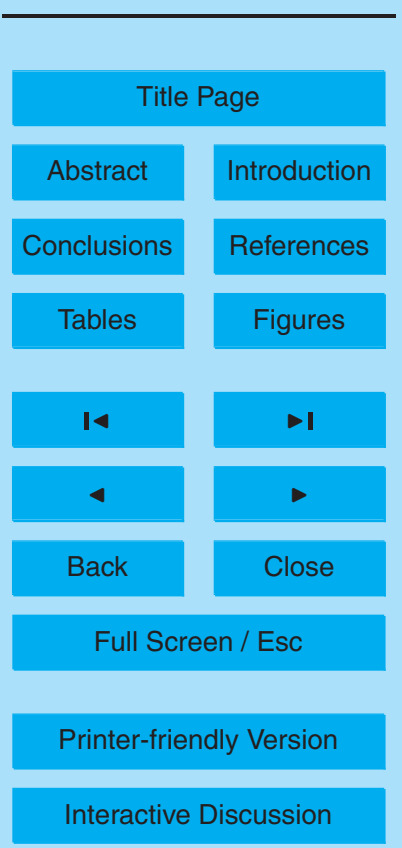




\section{ACPD}

7, 13805-13838, 2007

\section{Surfactants in} aerosols

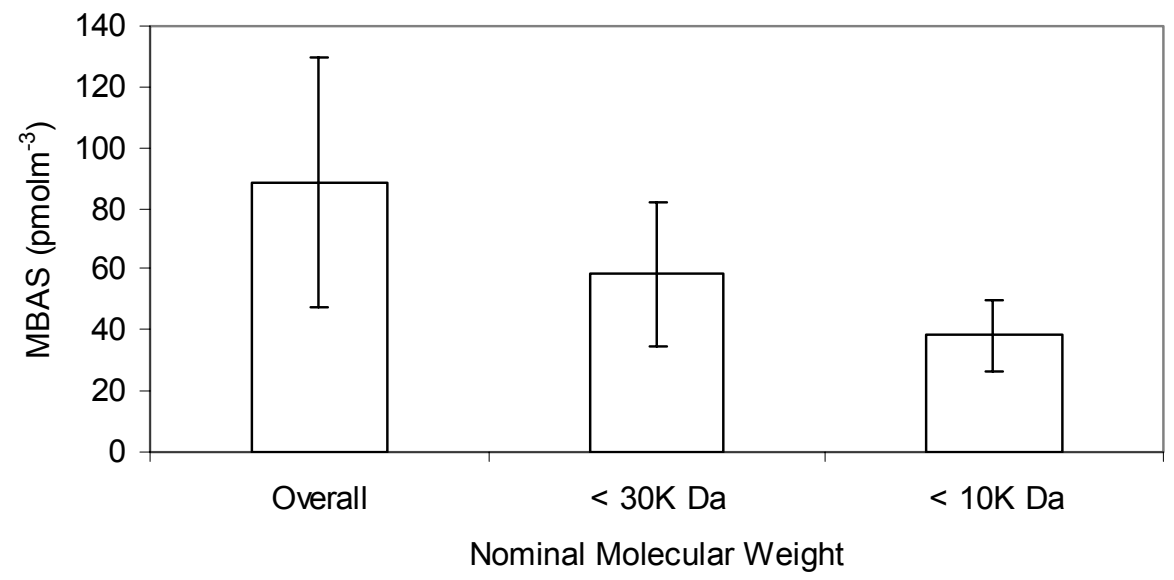

M. T. Latif and

P. Brimblecombe

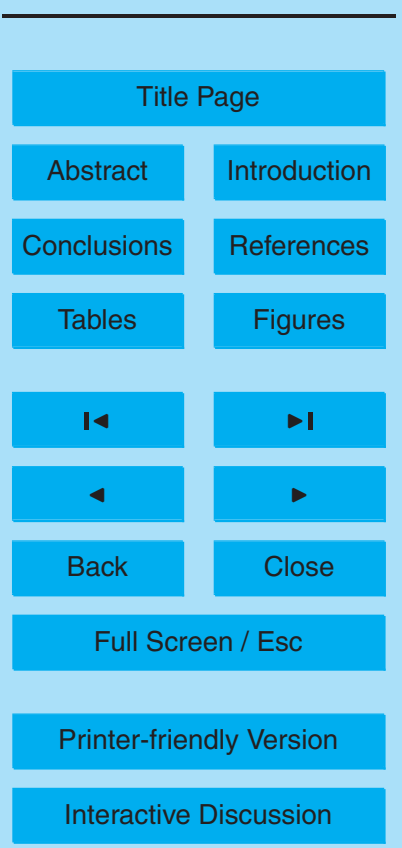

Fig. 8a. Separation of brown colour of aerosol extracts (Norwich station) and its MBAS surfactants concentration. 


\section{ACPD}

7, 13805-13838, 2007

\section{Surfactants in} aerosols

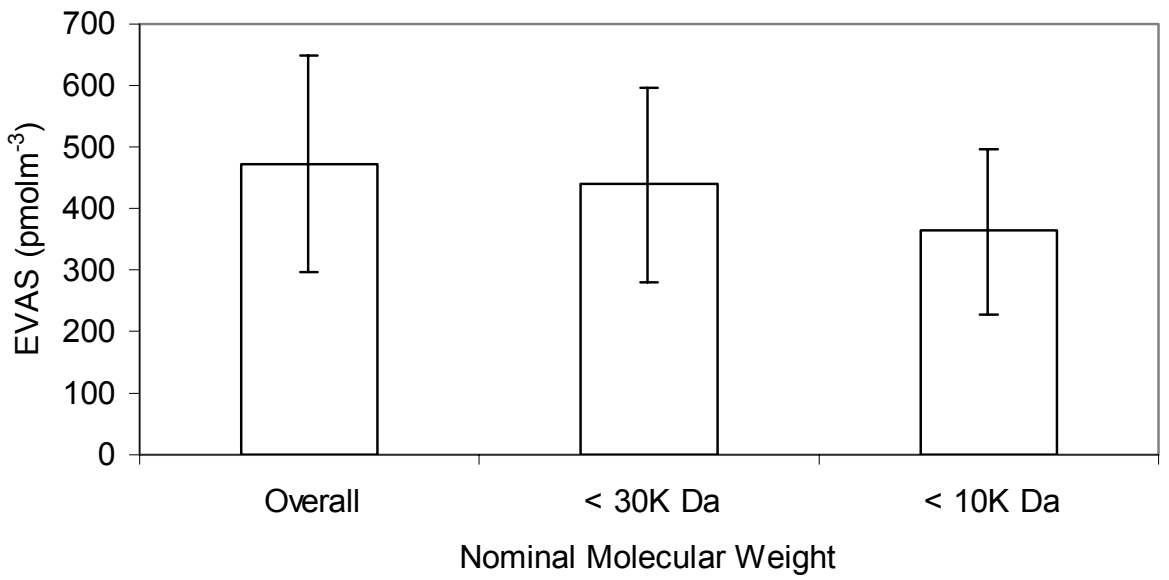

M. T. Latif and

P. Brimblecombe

Title Page

Abstract

Introduction

Conclusions

References

Tables

Figures

14

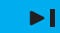

4

\section{Back}

Close

Full Screen / Esc

Printer-friendly Version

Interactive Discussion 


\section{ACPD}

7, 13805-13838, 2007

\section{Surfactants in} aerosols

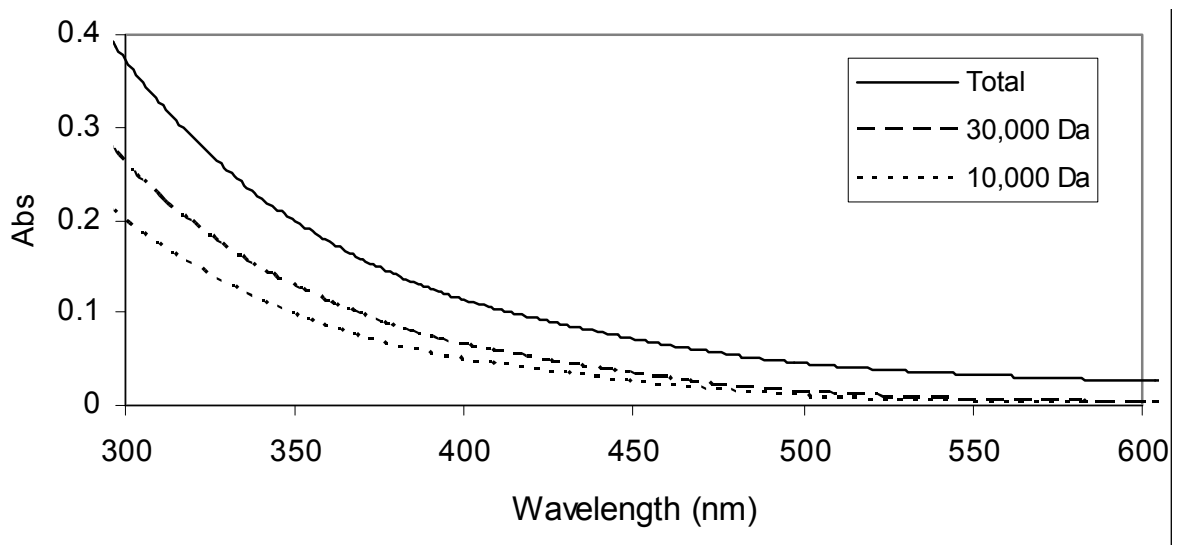

M. T. Latif and

P. Brimblecombe

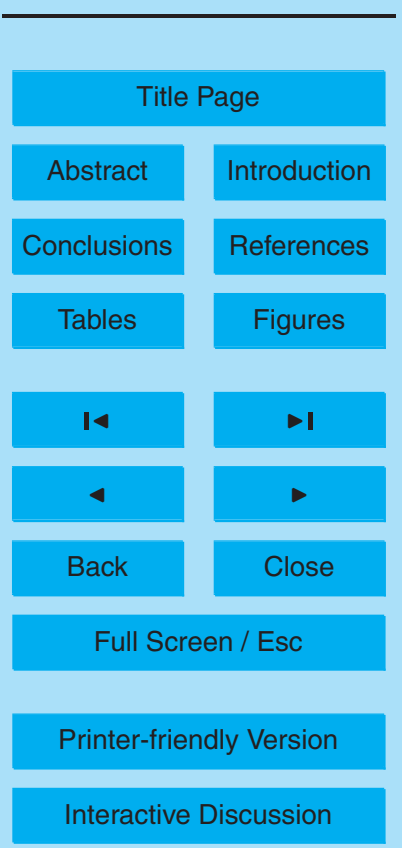




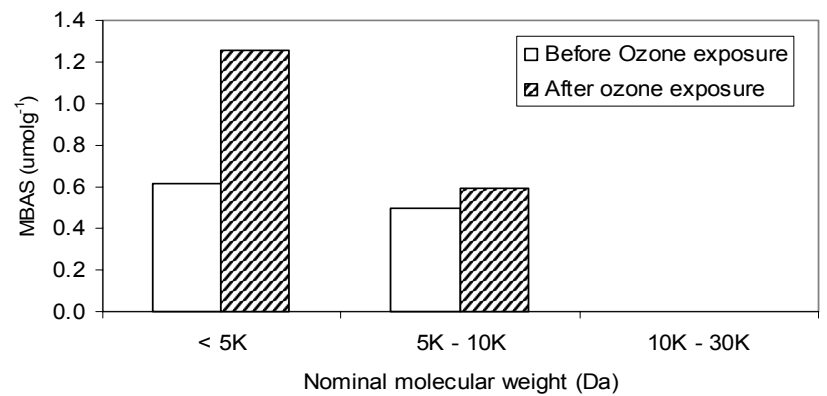

\section{ACPD}

7, 13805-13838, 2007

\section{Surfactants in} aerosols

M. T. Latif and

P. Brimblecombe

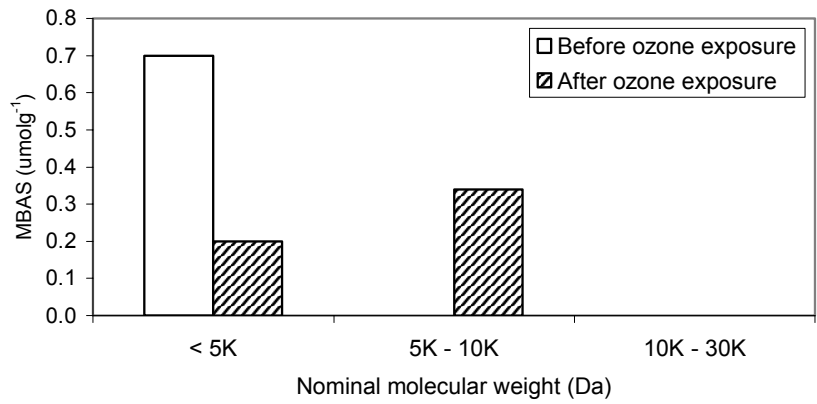

Title Page
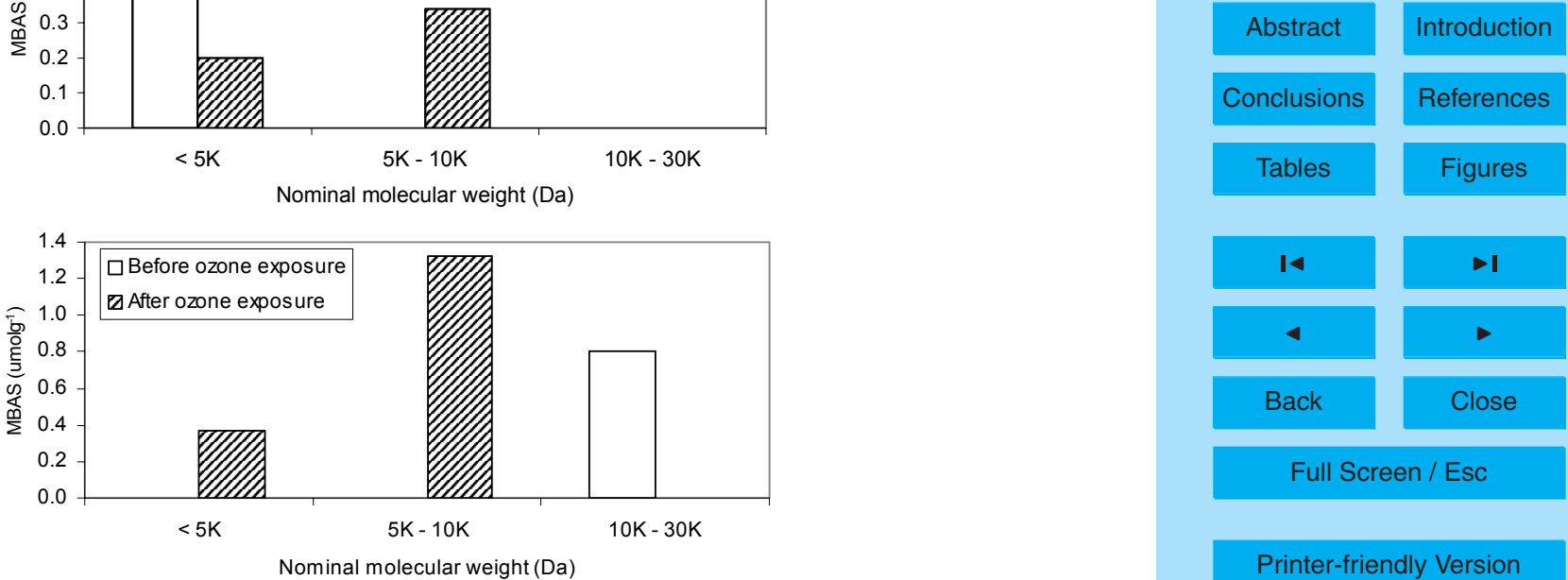

Printer-friendly Version

Interactive Discussion

Fig. 10. MBAS concentration of petrol soot, diesel soot and humic acid before and after expose to ozone. 


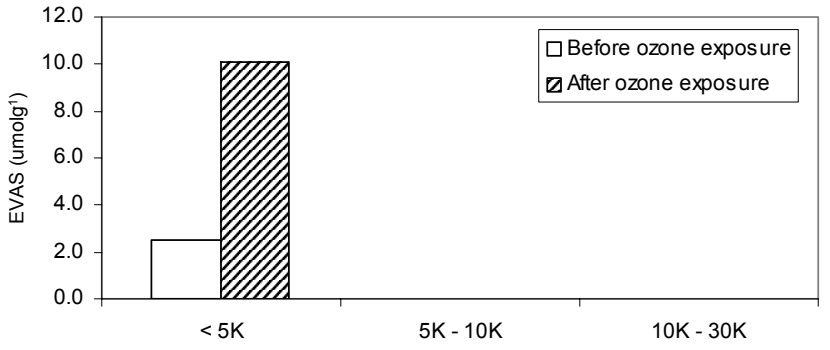

Nominal molecular weight (Da)
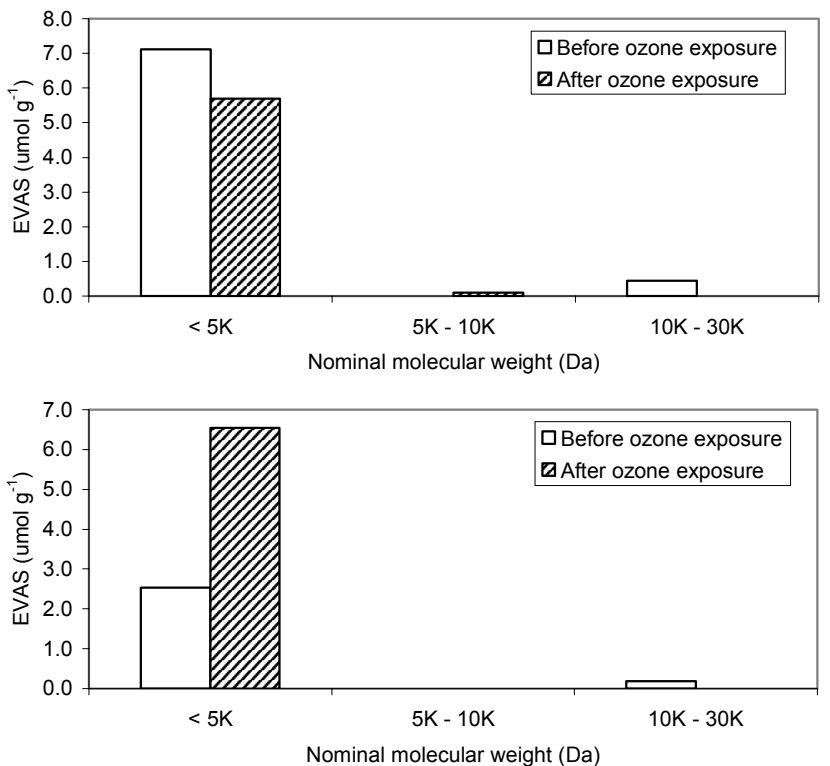

Fig. 11. MBAS concentration of petrol soot, diesel soot and humic acid before and after expose to ozone.

\section{ACPD}

7, 13805-13838, 2007

Surfactants in aerosols

M. T. Latif and

P. Brimblecombe

Title Page

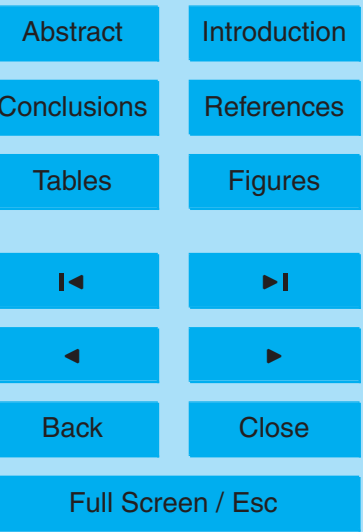

Printer-friendly Version

Interactive Discussion 